University of Pennsylvania Carey Law School

Penn Law: Legal Scholarship Repository

Faculty Scholarship at Penn Law

2003

\title{
Corporate Policy and the Coherence of Delaware Takeover Law
}

Richard E. Kihlstrom

The Wharton School, University of Pennsylvania

Michael L. Wachter

University of Pennsylvania Carey Law School

Follow this and additional works at: https://scholarship.law.upenn.edu/faculty_scholarship

Part of the Business Organizations Law Commons, Corporate Finance Commons, and the Law and Economics Commons

\section{Repository Citation}

Kihlstrom, Richard E. and Wachter, Michael L., "Corporate Policy and the Coherence of Delaware Takeover Law" (2003). Faculty Scholarship at Penn Law. 71.

https://scholarship.law.upenn.edu/faculty_scholarship/71

This Article is brought to you for free and open access by Penn Law: Legal Scholarship Repository. It has been accepted for inclusion in Faculty Scholarship at Penn Law by an authorized administrator of Penn Law: Legal Scholarship Repository. For more information, please contact PennlawIR@law.upenn.edu. 


\title{
CORPORATE POLICY AND THE COHERENCE OF DELAWARE TAKEOVER LAW
}

\author{
RICHARD E. KIHLSTROM ${ }^{\dagger} \&$ MICHAEL L. WACHTER ${ }^{\dagger}$
}

\section{INTRODUCTION}

Does the Delaware case law, which gives management considerable discretion to defeat a hostile tender offer, rest on unsupportable and inconsistent assumptions? ? $^{1}$ A number of leading corporate law scholars have made exactly that claim. For example, Ronald Gilson argues that the Delaware standard of management discretion is formalistic and incoherent, lacking an animating principle that explains why it protects shareholders' interests. ${ }^{2}$ More recently, Bernard Black and Reinier Kraakman have proposed principles to explain Delaware

\footnotetext{
${ }^{+}$Miller Friedman Professor of Finance, University of Pennsylvania.

${ }^{+t}$ William B. Johnson Professor of Law and Economics and Co-Director of the Institute for Law and Economics, University of Pennsylvania.

Thanks to William Allen, Lucian Bebchuk, Bernard Black, Ronald Gilson, Hon. Leo Strine, Edward Rock, and Alan Schwartz for their comments. Research assistance was provided by Bonnie Clause, Gregory Duffy, and Stephen Smulowitz. Library assistance was provided by William Draper. This research was supported by the University of Pennsylvania's Institute for Law and Economics.

The legal rule for Delaware corporations is developed in Unocal Corp. v. Mesa Pe troleum Co., 493 A.2d 946 (Del. 1985) and Unitrin, Inc. v. American General Corp., 651 A.2d 1361 (Del. 1995). The Delaware Supreme Court has stated the Unocal intermediate level of scrutiny as follows:

[B] efore the business judgment rule is applied to a board's adoption of a defensive measure, the burden will lie with the board to prove (a) reasonable grounds for believing that a danger to corporate policy and effectiveness existed; and (b) that the defensive measure adopted was reasonable in relation to the threat posed.

Paramount Communications, Inc. v. Time, Inc. 571 A.2d 1140, 1152 (Del. 1989) (citing Unocal, 493 A.2d 946). In Unitrin, the court held that the board of directors can retain takeover defenses if those defenses are neither coercive nor preclusive and fall within a range of reasonableness. Unitrin, $651 \mathrm{~A} .2 \mathrm{~d}$ at 1367 . The primary exception is when the board of directors' actions have effectively put the company up for sale. Under such circumstances, Revlon, Inc. v. MacAndrews E' Forbes Holdings, Inc., 506 A.2d 173 (Del. 1986) establishes that directors must maximize shareholder value.

${ }^{2}$ See Ronald J. Gilson, Unocal Fifteen Years Later (And What We Can Do About It), 26 DEL. J. CORP. L. 491, 492 (2001) (arguing that Unocal has developed into "an unexplained and ... inexplicable preference that control contests be resolved through elections rather than market transactions").
} 
corporation law based on what they call a "hidden value" model. ${ }^{3}$ However, they quickly conclude that the Delaware takeover cases are inconsistent with their reading of the empirical evidence and with each other. In both critiques, the case law is characterized as contradictory with any "sensible allocation of power between managers and shareholders," allowing managers to entrench themselves." Entrenchment occurs when managers maintain takeover defenses even when they believe that the hostile tender offer is in the best interest of shareholders. Critics of the Delaware approach favor an alternative standard, which provides for considerably more shareholder choice; essentially allowing shareholders rather than managers to decide the outcome of contests for control. ${ }^{5}$ There have been fewer supporters

${ }^{3}$ See Bernard Black \& Reinier Kraakman, Delaware's Takeover Law: The Uncertain Search for Hidden Value, 96 NW. U. L. REV. 521, 522 (2002) (explaining "hidden value" to be the true or intrinsic value of a firm "that a hard-working board can assess, but that remains invisible to shareholders and potential acquirers"); infra text accompanying notes $32-40$.

${ }^{4}$ Black \& Kraakman, supra note 3, at 521. After showing that the "hidden value" model explains some elements of Delaware case law, Black and Kraakman then seek to show that other features of the law are inconsistent with their model. See id. at 545-50 (noting that the hidden value model cannot fully justify the court's positions on deal protection measures, stock-for-stock acquisitions, and the ability of directors to "just say no"). However, if the hidden value model is intended to be a positive theory, then it fails to accomplish this goal. One cannot assert that one has developed a positive theory and then conclude that the case law is inconsistent with the positive theory.

${ }^{5}$ The shareholder choice model was first developed in the early 1980 s by Ronald J. Gilson, A Structural Approach to Corporations: The Case Against Defensive Tactics in Tender Offers, 33 STAN. L. REV. 819 (1981); Frank H. Easterbrook \& Daniel R. Fischel, The Proper Role of a Target's Management in Responding to a Tender Offer, 94 HARV. L. REV. 1161 (1981) and Lucian Arye Bebchuk, The Case for Facilitating Competing Tender Offers, 95 HARV. L. REV. 1028 (1982). Later articles taking this position include Lucian Arye Bebchuk, The Case Against Board Veto in Corporate Takeovers, 69 U. CHI. L. REV. 973 (2002); Lucian Arye Bebchuk et al., The Powerful Antitakeover Force of Staggered Boards: Further Findings and a Reply to Symposium Participants, 55 STAN. L. REV. 885 (2003); John C. Coffee, Jr., The Bylaw Battlefield: Can Institutions Change the Outcome of Conporate Control Contests?, 51 U. MIAMI L. REV. 605 (1997); Gilson, supra note 2; and Jeffrey N. Gordon, "Just Say Never?" Poison Pills, Deadhand Pills and Shareholder Adopted Bylaws: An Essay for Warren Buffet, 19 CARDOZO L. REV. 511 (1997). The shareholder choice position can, for expositional purposes, be identified with the Delaware Chancery Court's holding in Interco. According to Interco's reasoning, target management could use its poison pill to hold off the immediate clutches of an unwanted suitor. But the firm would eventually have to be sold, possibly to the existing management team should it mount a management buy-out ("MBO"), unless the shareholders could be quickly convinced to value the current earnings prospects of the firm more highly. City Capital Assoc. v. Interco Inc., 551 A.2d 787, 802 (Del. Ch. 1988). 
of the Delaware court's position, with the earliest and most vocal being Martin Lipton. ${ }^{6}$

The landmark Delaware case that provided for management discretion in the context of a hostile tender offer is Paramount Communications, Inc. v. Time, Inc. (hereinafter "Time-Warner"). In that case, the Delaware Supreme Court permitted Time to complete a strategic merger with Warner despite an all-cash bid by Paramount to buy Time at a substantial premium to the market price. In addition, the supreme court used Time-Warner to jettison an emerging chancery court doctrine that limited management's ability to maintain takeover defenses, specifically a poison pill, to a period only long enough to develop an alternative transaction. The Time-Warner decision was interpreted as fortifying the power of a board to "just say no" to an uninvited tender offer, thereby tilting the balance strongly toward management discretion and away from shareholder choice. ${ }^{9}$ The bidder could still succeed, but only by either mounting a proxy contest for board seats or encouraging financial market pressure to force target management to accept the bid.

${ }^{6}$ See, e.g., Martin Lipton, Takeover Bids in the Target's Boardroom 35 BUS. LAW. 101, 103-04 (1979) (writing pre-Unocal that, "the usual rule that directors may accept or reject a takeover bid if they act on a reasonable basis and in good faith should continue ... [as $\mathrm{t}$ ] akeover bids are not so different from other major business decisions as to warrant a unique sterilization of the directors").

${ }^{7} 571$ A.2d 1140 (Del. 1989).

${ }^{8}$ This emerging doctrine was first espoused by Chancellor Allen in City Capital Associates $v$. Interco Inc., 551 A.2d 787, 790-91 (Del. Ch. 1988). The Interco line of reasoning would give management only a limited period of time to develop alternatives to a noncoercive takeover bid, at which point any defenses would have to be removed. Id. at 798. To this, the Delaware Supreme Court replied that Interco,

represents a fundamental misconception of our standard of review under Unocal principally because it would involve the court in substituting its judgment as to what is a "better" deal for that of a corporation's board of directors. To the extent that the Court of Chancery has recently done so in certain of its opinions, we hereby reject such approach as not in keeping with a proper Unocal analysis.

Paramount, 571 A.2d at 1153.

${ }^{9}$ See, e.g., Jeffrey N. Gordon, Comporations, Markets and Courts, 91 CoLUM. L. REV. 1931, 1932 (1991) (arguing that the Delaware Supreme Court's deference to management is equivalent to explicitly sanctioning a "just say no" defense); Joseph $A$. Grundfest, Just Vote No: A Minimalist Strategy for Dealing with Barbarians Inside the Gates, 45 STAN. L. REV. 857, 859 n.4 (1993) (noting that the decision would likely deter hostile bids); Lyman Johnson \& David Millon, The Case Beyond Time, 45 BUS. LAW. 2105 , 2109 (1990) (remarking that the Delaware Supreme Court's treatment of Time under Unocal's second step "decisively locat[ed] authority over the totality of corporate affairs ... with directors rather than shareholders"). 
Now fourteen years after the Delaware Supreme Court's pivotal decision in Time-Wamer, few have offered a model that can explain the logic of the case to justify the court's preferences for management discretion over shareholder choice in deciding the outcome of contested control transactions. ${ }^{10}$

In this Article we provide what we believe to be the first formal model to explain Delaware corporate case law with respect to takeover defenses." The goal is thus to develop the animating principles under which management discretion is arguably the appropriate standard for takeover defenses, with the corollary that Time-Wamer was correctly decided. $^{12}$ As we will show, the key to the court embracing management discretion in Time-Warmer was the development of a threat to the corporate policy as a cognizable threat under Unocal's standard of review. $^{13}$ In most of the cases preceding Time-Wamer, the threats that

${ }^{10}$ The two major exceptions are the aforementioned article by Black and Kraakman, supra note 3 , and an article by one of us, written concurrently with that piece. Michael L. Wachter, Takeover Defenses When Financial Markets Are (Only) Relatively Efficient, 151 U. PA. L. REV. 787 (2003). The present Article builds on the latter article by Wachter.

"There are many components of the Delaware courts' management discretion rule. These include, among others, whether deal protection devices should be accorded business judgment rule protection and whether combining defenses such as the poison pill and a staggered board represent a preclusive and thus wrongful defensive measure. This Article does not take on those collateral questions, but instead focuses on what we believe to be the defining assumptions underpinning the management discretion rule.

${ }^{12}$ Because the Delaware Supreme Court has been widely criticized for its opinion in this case, we point out that any villainy awards need to be shared with Chancellor William Allen, since his chancery court opinion in that case provided the critical elements underpinning the supreme court's opinion. See Paramount, 571 A.2d at 1150-51, 1154-55, affg, Nos. 10866, 10670, 10935, 1989 Del. Ch. LEXIS 77 (Del Ch. July 17, 1989) (agreeing with and building upon Chancellor Allen's rejection of Revlon duties and following his determination under Unocal that management had the right to choose to carry forward a pre-existing transaction, even in an altered form).

${ }^{13}$ While Unocal used the term "threat to corporate policy," Unocal Corp. v. Mesa Petroleum Co., 493 A.2d 946, 955 (Del. 1985), that case dealt with a two-tier, frontloaded offer, where the remaining shareholders in the back end would receive junk bonds worth less than the cash offered in the front end. Id. at 956. Rather than discussing any element of Unocals future strategy, the court instead focused on the fact that "such offers are a classic coercive measure designed to stampede shareholders into tendering ...." Id.

In Paramount, the court differentiated the threat posed by Paramount's hostile tender offer from earlier cases where the threat cited by target corporations was either a threat of coercion resulting from unequal treatment for nontendering shareholders or the threat of inadequate value. Instead, the court noted that Time's board believed that its "shareholders might elect to tender into Paramount's cash offer in ignorance or a mistaken belief of the strategic benefit which a business combination with Warner 
satisfied the first prong of Unocal were threats to shareholders in the form of coercion or some inchoate reference to inadequate value. Time-Warmer recognized a threat to corporate policy that is separable from a threat to shareholders. ${ }^{14}$

Using a threat to corporate policy to satisfy the first prong in Unocal's two-part analysis significantly changed the analysis of the second prong. What degree of management discretion is "reasonable" under the second prong depends on the nature of the threat under the first prong. ${ }^{15}$ Between the Delaware Supreme Court decisions in Revlon and Time-Warner, target boards frequently responded to hostile tender offers by proposing a financial restructuring of the corporation, while using takeover defenses to effectively force acceptance of their proposed restructuring. ${ }^{16}$ We argue below that such action is an unreasonable response when the threat posed is inadequate value of a financial restructuring. In that case, shareholders are well informed and well suited to determine the value of alternative financial restructuring plans so that using takeover defenses unduly thwarts an informed choice by shareholders. This changes, however, when the target board responds by continuing to pursue an existing informed corporate policy while using takeover defenses to support that action. In this case, managers are arguably well informed and shareholders are not, so that it is reasonable to allow greater management discretion in choosing a response to a threat posed to corporate policy.

For a satisfactory explanation of the case law, we provide a theoretical framework in which corporate policy is explicitly modeled in the context of occasional financial market mispricing. Our focus on corporate policy is a break with the previous debate on takeover defense law. That debate has largely ignored corporate policy, treating it as an academic black box, and it has insisted on the complete

might produce." Paramount, $571 \mathrm{~A} .2 \mathrm{~d}$ at 1153 . Essentially, this is the first case where the court had to focus on a specific corporate policy-in this case a planned mergerand whether that policy would satisfy Unocal's first prong.

${ }^{14}$ Paramount, $571 \mathrm{~A} .2 \mathrm{~d}$ at 1154.

${ }^{15}$ See supra note 1 (explaining Unocal's two-prong analysis).

${ }^{16}$ See, e.g., Ivanhoe Partners v. Newmont Mining Corp., 535 A.2d 1334, 1339, 1343 (Del. 1987) (upholding a restructuring proposal designed to reduce liquidity and a defensive scheme consisting of a dividend, standstill agreement, and street sweep); Robert M. Bass Group, Inc. v. Evans, 552 A.2d 1227, 1229-31, 1244 (Del. Ch. 1988) (rejecting a proposal that would give certain members of management absolute control and that would be supported by a shareholder right's plan); AC Acquisitions Corp. v. Anderson, Clayton, \& Co., 519 A.2d 103, 113 (Del. Ch. 1986) (concluding that a partial liquidation restructuring and self-tender offer were unreasonable defensive steps and could not stand against the second prong of the Unocal test). 
efficiency of financial markets. These are fundamental mistakes that we propose to correct. We also focus primarily on the effect that legal rules have on the corporate policy decisions made prior to the emergence of a hostile bid but in anticipation of the possibility that one might arise. The focus is not new since the traditional defense of greater shareholder choice is that a competitive market for corporate control disciplines managers in a way that reduces agency costs. While recognizing the discipline of the market for corporate control, our model introduces a distinct incentive effect on managers that works in the opposite direction.

This then is the critical insight of the corporate policy model in the context of occasional market mispricing: managers who wish to extend their job tenure can best achieve this goal by managing to the market's implicit assessments. By so doing, the managers can best maximize the stock price in each period and minimize the possibility of market underpricing that would make the managers vulnerable to a hostile offer. In effect, managers in each period forego unpopular investment opportunities in favor of popular ones, as assessed by the market rather than by their own assessment of the discounted cash flows that the investments will generate. If, as seems plausible, managers have better information than the market about specific investment opportunities, managing to the market fails to maximize the value of the corporation over time.

Corporate policy becomes a decisive variable when there are limits to the efficiency of financial markets. Limits to market efficiency are commonly assumed in the finance literature and it is uncontroversial even for those who believe that financial markets are generally efficient. $^{17}$ It does, however, imply a failure of strong form market efficiency. Essentially, there are times when managers have better information than the market as to the corporation's value (that is, the pro rata value of the discounted free cash flows generated by a company's existing assets and investment opportunities). As we interpret the assumption, the market knows what the managers might know and with what probability. The managers use their information to determine corporate policy and their valuation of the firm reflects their privileged information. Because the market simply uses its expectations to

\footnotetext{
${ }^{17}$ See infra notes 58-63. This point is similar to the point made in Jeremy C. Stein, Takeover Threats and Managerial Myopia, $96 \mathrm{~J}$. POL. ECON. 61 (1988). Stein focuses on "managerial myopia" and the contention "that takeover pressure ... leads managers to focus more heavily on short-term profits rather than on long-term objectives. Id. at 62.
} 
value the firm, managers sometimes value the firm more highly than the market and sometimes the market's valuation is higher.

The problem for corporate law arises in a world where there are agency costs resulting from managers' interest in retaining their position. Because of these costs, there is no credible way for the managers to reveal that their valuation is high when it truly is. Similarly, it follows that when the managers have a low valuation they not only have no incentive to reveal that fact, but they also may claim a high valuation because there is no way the market can determine that they have misrepresented their position.

We model corporate policy as the investment or capital expenditure (CAPX) decision that managers adopt in a given period. When the managers are better informed than the market as to the value of alternative investment opportunities, they face a choice: make decisions that rely on their own information as to the future value of investment opportunities or make decisions that rely on the market's implied value of investment opportunities. When managers rely on their superior information to set corporate policy they make valueenhancing investment decisions. We refer to this as the "valuecreating" corporate policy. We show that in a shareholder choice regime, managers may feel pressured to manage to the market's information, thereby foregoing value-creating investment opportunities.

However, providing managers with the freedom to ignore financial market valuations when setting corporate policy raises the potential that managers may use that discretion to act in their own interest rather than in the interests of the corporation. This problem was recognized by the Delaware Supreme Court in Unocal when it noted the omnipresent threat of management entrenchment. ${ }^{18}$

Despite agency cost problems with management discretion, we argue that a legal rule favoring shareholder choice raises its own, heretofore unappreciated, agency costs and this arguably exacerbates, rather than reduces, total agency costs. ${ }^{19}$ In our model, managers

IB See 493 A.2d at 954 ("Because of the omnipresent specter that a board may be acting primarily in its own interests, rather than those of the corporation and its shareholders, there is an enhanced duty which calls for judicial examination at the threshold before the protections of the business judgment rule may be conferred.").

${ }^{19}$ We assume that the choice set is between management discretion and shareholder choice. In Unocal, the court favored intermediate scrutiny. Id. at 955 (requiring a target board to establish that (i) it "had reasonable grounds for believing that a danger to corporate policy and effectiveness existed" and (ii) its choice of defensive measure was "reasonable in relation to the threat posed"). A standard of review that allowed for substantive review of the two prongs of the Unocal rule has failed to emerge 
impose agency costs when they choose to manage to the market even though they credibly believe that their own information is superior to the market's information. By managing to the market, managers can decrease the likelihood of underpricing or the degree of underpricing. However, the costs of choosing corporate strategies that the market prefers, but which managers believe are suboptimal, are lost opportunities to adopt value-enhancing investments. This reduces the value of the corporation below its potential.

In Part I, we briefly discuss the prior models of Delaware corporate law. In Parts II and III, we outline our two approaches and, in the process, discuss the issues of market efficiency that play a critical role in deciding on the relative attractiveness of the management discretion and shareholder choice models. In Part IV, we present the first model of corporate policy and develop the theme of value-creating investment opportunities based on management's superior information. There are no agency costs in this model. In Part V, we present a second model that allows for agency costs. In this second model, we develop the surprising result that shareholder choice may exacerbate the agency cost problem. In Part VI, we use the two models to explain key components of Delaware corporate law, including the chancery and supreme court's reasoning in the Time-Warner litigation and the inherent weaknesses of the Interco line of cases. We conclude by expanding on the implications of our model of corporate policy.

\section{THE LITERATURE ON THE BASIC PRINCIPLES UNDERLYING THE DELAWARE MODEL}

Our Article falls within a small class of articles that have attempted to provide a coherent justification for the Delaware court's takeover doctrine. There is a body of literature that examines the statutory basis and/or the internal consistency of the management discretion rule across case law. ${ }^{20}$ But this literature cannot resolve the debate between

to date. See Gilson, supra note 2, at 497 ("In deference to Delaware's traditional respect for the business judgment role dictates, the chancery court . . recast[] Unocal in terms of an allocation of decision-making roles not between the board and the court, but between the board and the shareholders."). We do not take on the task here of attempting to create a substantive intermediate level of scrutiny that would fall between the two polar cases of management discretion and shareholder choice.

${ }^{20}$ Two influential articles are Ronald J. Gilson \& Reinier Kraakman, Delaware's Intermediate Standard for Defensive Tactics: Is There Substance to Proportionality Review?, 44 BUS. LAW. 247 (1989), which examines Unocals intermediate standard of review and proposes a model proportionality test, and Marcel Kahan, Paramount or Paradox: The 
management discretion and shareholder choice because there is ample evidence to support either type of rule within the statutory framework and existing case law.

Our approach poses a broader question: are there animating principles that support a claim that management discretion, at least in some important circumstances, is superior to shareholder choice? $?^{21}$ Our answer, developed below, is that such principles can be found by developing a model of corporate policy in the context of financial markets that allow for occasional mispricing.

Martin Lipton was the first to offer a broad defense of the Delaware rules. ${ }^{22}$ Recently, Lipton and Paul Rowe laid out the building blocks of their version of the management discretion rule. ${ }^{23}$ Their support for such a rule is based on three claims. First, financial markets are highly inefficient, so that a shareholder choice regime allows companies to be purchased at far below the value of the corporation. ${ }^{24}$ Included within this claim is the assertion that takeovers maximize shareholders' short-term gains, with the inference that this may conflict with shareholders' long-term interests. ${ }^{25}$ Second, managers of corporations in a contested-control setting can be trusted to act in the best interest of their shareholders. ${ }^{26}$ Third, the current system-at least post-Time-Warner-is not broken, so why fix it? ${ }^{27}$

Delaware Supreme Court's Takeover Jurisprudence, 19 J. CORP. L. 583 (1994), which attempts to articulate the legal coherence of the supreme court's arguments.

${ }^{21}$ See Gilson, supra note 2, at 505 (asserting that in Delaware, "[ $\left.\mathrm{t}\right]$ he statute, like a golem, requires an animating principle to come alive").

${ }^{22}$ See Lipton, supra note 6, at 130-31 (arguing for management discretion).

${ }^{23}$ Martin Lipton \& Paul K. Rowe, Pills, Polls and Professors: A Reply to Professor Gilson, 27 DEL. J. CORP. L. 1, 2-3 (2002). Others who have favored greater management discretion over shareholder choice in the case of takeover defenses include Stephen M. Bainbridge, Director Primary: The Means and Ends of Corporate Governance, 97 Nw. U. L. REV. 547 (2003); Margaret M. Blair \& Lynn Stout, A Team Production Theory of Corporate Law, 85 VA. L. REV. 247 (1999); Lynn A. Stout, Bad and Not-So-Bad Arguments for Shareholder Primacy, 75 S. CAL. L. REV. 1189 (2002). For an attempt to strike a balance between the two regimes, see Marcel Kahan \& Edward B. Rock, Corporate Constitutionalism: Antitakeover Charter Provisions as Precomittment, 152 U. PA. L. REV. 473 (2003).

${ }^{24}$ See Lipton \& Rowe, supra note 23, at 3 ("[E]ven academic economists have increasingly recognized that the efficient market theory is fundamentally flawed.").

${ }^{25}$ See id. at 26 (indicating that short-term trading value should not be the sole reference point for responding to takeover proposals).

${ }^{26}$ See id. at 8 (arguing that the accusation that "directors were only capable of acting in their self-interest was unsupported by empirical evidence and inconsistent with the assumptions underlying the structure of American corporate law"). This is an unstated assumption throughout Lipton's articles. See, e.g., Martin Lipton \& Steven A. Rosenblum, A New System of Corporate Governance, 58 U. CHI. L. REV. 187, 195 (1991) (describing the assumption that corporate managers are inherently self-interested as 
There are two important weaknesses with the Lipton position. First, the claim that financial markets are highly and regularly inefficient does not support the claim that a management discretion legal regime is preferable to a shareholder choice regime. ${ }^{28}$ The reason is that, if financial markets never accurately price common shares, shareholders will never receive the fundamental value that managers claim exists. Instead, shareholders are better served if they are allowed to take the premium offer and simply reinvest it in other

"simply unfounded"); Lipton, supra note 6, at 123 n.68, 131 (arguing that takeover bids do not create a conflict of interests between directors and shareholders). But see Martin Lipton, Corporate Governance in the Age of Finance Corporatism, 136 U. PA. L. REV. 1, 5960 (1987) (proposing corporate governance legislation to "assure [] that corporations will be run for the long-term benefit of their shareholders ... rather than for the ... entrenched management"). Another assumption, although more whimsical and implied, is that academic commentators get it wrong and the Delaware courts that they criticize get it right. See Lipton \& Rowe, supra note 23, at 18-19 (" [T] study shows that there is no evidence that, after fifteen years, the poison pill or Delaware's jurisprudence has ever detracted from shareholder economic welfare.").

${ }^{27}$ "Critics of the Delaware model are not able to identify any substantial way in which the post-1985 case law has distorted Delaware's statutory model; has produced actual unfair or inefficient outcomes; or has damaged overall corporate of shareholder welfare." Lipton \& Rowe, supra note 23, at 2. Furthermore, Delaware law is the most shareholder-friendly of the major state corporate systems. See id. at 14 ("No jurisdiction in the United States went further than Delaware to adopt statutes or create case law that tightly restricts takeover defenses."). Indeed, the market even places a premium value on corporations that incorporate in Delaware. Robert Daines, Does Delaware Law Improve Firm Value?, 62 J. FIN. ECON. 525, 555 (2001). Certainly Lipton had a different view before Time-Warner, when he suggested to his corporate clientele that they consider reincorporating outside of Delaware. See Laurie P. Cohen, Lipton Tells Clients that Delaware May Not be a Place to Incorporate, WALL ST. J., Nov. 11, 1988, at B7 (noting Lipton's memo that suggested that "'[p]erhaps it is time to migrate out of Delaware"" (quoting Lipton)).

Lipton, however, goes beyond a defense of Delaware corporate law. Adhering to a position first advocated in 1979, Lipton supra note 6 , at 130 , he argues that decisions with respect to takeover defenses should be governed by the business judgment rule and that such decisions can take into account other constituent interests. Lipton \& Rowe, supra note 23 , at 35 . In particular, in deciding among competing offers for the company in a contested control setting, the managers should be able to choose the offer that best protects not only shareholder interests, but also the interests of employees and the community. Lipton supra note 6 , at 130 . In taking this position, Lipton is adhering to a vision first espoused by Merrick Dodd in the classic debate with Adolph Berle. Dodd argued that the corporation, being both a creation of the state and a social institution, has to protect societal interests and not merely those of shareholders. E. Merrick Dodd, Jr., For Whom are Corporate Managers Trustees?, 45 HARV. L. REV. 1145 , 1159-62 (1932). Compare id., with A. A. Berle, Jr., Corporate Powers as Powers in Trust, 44 HARV. L. REV. 1049, 1049 (1931) (contending that management must only act for "the ratable benefit of all shareholders as their interest appears"). This position goes well beyond Unocal/Unitrin in the degree of management discretion it allows.

${ }_{28}$ In fact, assuming that bidders are more informed than the market, an unfettered market for corporate control would actually improve market efficiency. 
securities. The related assertion that takeovers maximize short-term value rests on the flawed idea that financial markets are myopic, prizing managers who maximize short-run profits. We return to this issue immediately below in the discussion of the Black and Kraakman model, ${ }^{29}$ but we note here that there is no evidence to support this contention. ${ }^{30}$ Consequently, if financial markets are inefficient enough, a management claim that the firm is undervalued is hollow. Shareholders offered a premium bid by a hostile raider are better served to take the premium since the stock could easily become more undervalued in the future and there would be no reason to assume that the stock would ever be fairly valued.

Second, the Lipton position ignores the agency cost problem or, alternatively, simply assumes that managers act in the best interests of shareholders. This conflicts, however, with the Delaware Supreme Court's assertion in Unocal that heightened scrutiny is required in reviewing takeover defenses because of the "omnipresent specter that a board may be acting primarily in its own interests, rather than those of the corporation and its shareholders." ${ }^{31}$

The problem with such a position is that it provides a blank check to managers. Because there is no way of determining how much weight to apply to which group's interests, or why nonshareholder interests should be given any weight at all, the system devolves into one that merely states that managers should get to choose. Consequently, a business judgment standard is insufficient to handle the agency cost issues that arise in the context of takeover defenses.

Black and Kraakman present a more formal model of Delaware corporate law, calling it the "hidden value" model. ${ }^{32}$ They differentiate this model from the "visible value" model, which they favor. The hidden value model has strong parallels to the component of our model that deals with mispricing by financial markets. Black and

${ }^{29}$ See infra text accompanying notes $34-39$ (outlining the assumptions in Black \& Kraakman's work).

${ }^{30}$ The financial markets' recent exuberance over the long-term promise of the New Economy should be sufficient to dispel any remaining claims of stock market myopia.

${ }^{31}$ Unocal Corp. v. Mesa Petroleum Co., 493 A.2d 946, 954 (Del. 1985).

${ }^{32}$ See supra notes 3-4 (discussing the "hidden value" model). The term "hidden" is a misnomer. Managers may be quite explicit about their own estimate of the value of the corporation. They are even likely to disclose their assumptions as to future growth rates and discount rates. If anything, the market's pricing assumptions are more hidden. Although the market price is clear enough, that price is a single statistic with which any number of different cash flow and discount rate assumptions are compatible. 
Kraakman interpret the Delaware doctrine as resting on nine assumptions. ${ }^{99}$ Only five are actually needed to support hidden value. These specific assumptions track our assumptions that there is occasional financial market mispricing and that managers may have nonverifiable information superior to that available to the market. ${ }^{34}$

Of the remaining four assumptions, ${ }^{35}$ we disagree with two, one of which is pivotal. In particular, we disagree with the claim that the Delaware courts' management discretion rule is unconcerned with agency costs and assumes that boards always use their informational advantage in the shareholders' interest. ${ }^{96}$ A major innovation of this Article is that it sets forth a corporate policy model that is consistent with Delaware's Unocal doctrine and includes agency costs.

The second assumption with which we disagree is less central, but nonetheless informative. According to Black and Kraakman, Delaware law assumes that long- and short-term shareholders have different interests and favors the interests of long-term shareholders. ${ }^{37}$ We agree with Black and Kraakman that this assumption is incorrect, ${ }^{38}$ but do not believe that it fits into a positive theory of Delaware takeover law. ${ }^{39}$ We elaborate on this point in our discussion of Time-Wamer. ${ }^{40}$

${ }^{33}$ See Black \& Kraakman, supra note 3, at 529-33 (describing the assumptions underlying the hidden value model of Delaware law).

${ }_{34}$ The five necessary Black and Kraakman assumptions are (1) the board of directors has private information as to the value of the corporation, (2) the information cannot be easily communicated to the market, (3) any resulting valuation gap can be large, (4) valuation gaps can persist for some period of time, and (5) the market for corporate control is not competitive enough to eliminate the valuation gap. Id. at 52931 .

${ }^{35}$ The four remaining assumptions are (1) target boards are more trustworthy than shareholders believe, (2) long- and short-term investors have different interests and the interests of long-term investors should drive corporate policy decisions, (3) an investment banker's opinion provides a check for management's assessment of hidden value, and (4) the interests of undiversified investors are more important than those of diversified investors. Id. at 530-33.

${ }^{36}$ See id. at 531 ("To justify allowing the board's view on value to trump a contrary shareholder view, one must also believe that boards that reject takeover bids are usually trustworthy, and shareholders wrongly distrust these board decisions.").

${ }^{37}$ Id. at 532.

${ }^{38}$ Id. at 532-33 (arguing that short-term shareholders also have an incentive to maximize a firm's long-term value "because only by doing so can they maximize the price at which long-term investors will buy the shares that [they] will soon want to sell").

The Delaware Supreme Court may have come close to stating this erroneous position in Time-Warner, but the court's perspective in that case was based on a misunderstanding of the chancery court's argument. We discuss this issue below when we discuss the chancery court and supreme court decisions in Time-Warner. See infra text accompanying notes 110-30 (detailing the difference apparent in Time-Wamer and sub- 
An Article by one of us, written concurrently with the Black and Kraakman article, also describes the key underpinnings of the Delaware model. ${ }^{41}$ It shares many of the same features as their model, also pivoting off the existence of an intrinsic value for a corporation based on the free cash flow generated by the corporation's assets. Some degree of financial market inefficiency is included, but it is presumed to be sporadic and transitory, in distinction to the assumption made by Lipton. ${ }^{42}$ Managers are assumed to have private information that cannot be verified by the market so that managers are, at times, better informed than the market. ${ }^{43}$

The Wachter article shows that a shareholder choice regime loses many of its advantages in a world where markets are only relatively efficient. When market mispricing exists, shareholders are not derivatively fully informed and thus may be undercompensated for their shares. Moreover, if mispricing occurs, corporations may be subject to hostile tender offers, not only when there are high agency costs, but also when the mispricing is most severe. This weakens the disciplinary signal effect of the market for corporate control. Finally, managers may respond to mispricing by managing to the market, thereby creating new agency problems. ${ }^{44}$

This Article builds on the earlier one by Wachter ${ }^{45}$ by providing a specific model of corporate policy. This enables us to develop more fully two related themes. The first is the centrality of corporate policy. The second theme is the need to broaden the concept of agency costs to include the indirect agency costs that result when managers alter corporate policy with the goal of entrenchment.

sequent cases between Delaware's stance toward shareholder choice and management policysetting activities).

40 Infra text accompanying notes 123-26.

Black and Kraakman suggest two other assumptions that we believe are unnecessary. The first is that an investment banker's opinion is a credible check on the target board's claim of hidden value. Black \& Kraakman, supra note 3 , at 531 . The second assumption is that "the interests of undiversified investors count more than those of diversified investors." Id. at 533 (internal formatting omitted).

"11 See generally Wachter, supra note 10.

42 Compare id. at 817 ("[M] $[\mathrm{Mrkets,} \mathrm{although} \mathrm{not} \mathrm{entirely} \mathrm{efficient,} \mathrm{are} \mathrm{relatively} \mathrm{effi-}$ cient as defined by CAPM/ECMH."), with Lipton \& Rowe, supra note 23, at 2 (arguing that markets are highly inefficient).

${ }^{13}$ See Wachter, supra note 10 , at 818 (noting that managers are privy to inside information regarding asset- or project-specific cash flows and discount rates).

${ }^{44} I d$. at $823-24$.

Id. at 818 . 


\section{Corporate POlicy AND the Fundamental VALUE OF THE Firm}

What do we mean by corporate policy and why is it important to understanding the Delaware takeover defense law? We view corporate policy as the set of strategic business decisions that a firm adopts which have material effects on the corporation's value. Following Hart and others, we take the corporation to be the collection of physical and intangible assets over which the firm has rights of residual control. ${ }^{46}$ Based on core principles of corporate finance, and consistent with the practices of financial officers and their advisors, the fundamental value of the corporation is the sum of the discounted stream of free cash flows (DCFs) that is generated by the assets over which the corporation has residual control rights. In Delaware law, the courts often describe this as the "intrinsic value" of the corporation. ${ }^{47}$ For our purposes the intrinsic value of the corporation is its fundamental value.

If real capital is at the core of the firm, the company's capital program (i.e. the decision to build, buy, or sell assets) will be central to maximizing the value of the firm. Many of these decisions result in transactions that affect a small fraction of the firm's assets. Some decisions represent much larger changes in the firm's overall asset mix. Time's planned merger with Warner is an example of the latter. ${ }^{48}$

Accordingly, we define a firm's (simple) corporate policy as its current-period investment decision. ${ }^{49}$ The investment decision includes the purchase of new physical and intangible assets, the sale of

${ }^{46}$ See Oliver Hart, An Economist's Perspective on the Theory of the Firm, 89 CoLUM. L. REv. 1757, 1765-66 (1989) (viewing a firm as a set of property rights including asset ownership and residual control rights); see aiso Edward B. Rock \& Michael L. Wachter, Islands of Conscious Power: Law, Norms, and the Self-Governing Comporation, 149 U. PA. L. REV. 1619, 1634-35 (2001) (describing the property rights theory of the firm as defining a corporation by its physical or intangible capital and its residual rights of control over that capital).

${ }^{47}$ See, e.g., Rapid-Am. Corp. v. Harris, 603 A.2d 796, 806 (Del. 1992) ("Recent price changes in the stock market dramatically illustrate the defects of an overstated reliance on market price to determine a corporation's intrinsic value ...."); Weinberger v. UOP, Inc., No. 5642, 1985 Del. Ch. LEXIS 378, at*21 (Del. Ch. Jan. 30, 1985) (" $[\mathrm{W}]$ hat is meant by 'the stockholder's proportionate interest in the corporate enterprise' is 'the true or intrinsic value of his stock which has been taken by the merger." (quoting Tri-Continental Corp. v. Battye, 74 A.2d 71, 72 (1950))).

${ }_{48}$ See Paramount Communications, Inc. v. Time, Inc., 571 A.2d 1140, 1143 (Del, 1989) (discussing the planned merger of Time and Warner as a method for expanding Time's operations from journalism into a vertically integrated video enterprise).

${ }^{49}$ Obviously, a corporate policy will entail more than the planned capital program. For purposes of this Article, however, this definition suffices. 
existing assets, the purchase of some or all of another company's assets, the merger with another company, and any other transaction that, at its core, is asset-driven. We view corporations as making these investment decisions repeatedly and periodically, thus constantly updating and revising their corporate policies as the results of these investments become known.

Corporate policy includes both the investment decision in the physical or intangible assets and the financing decision that secures financial capital. For purposes of our analysis, we identify corporate policy with the investment in real assets. Managers making decisions regarding investment in real assets will almost always have superior information since they are most knowledgeable about the outlook for their product markets and the best techniques of production. The same is not true of financing decisions, in which financial markets will have at least equal information regarding the key variable-the cost of securing capital for the firm.

Our description of corporate policy is consistent with the Delaware Supreme Court's discussion of so-called enterprise decisions. According to Chief Justice Veasey, "Enterprise issues raise questions such as: should we manufacture cars or widgets, and should the plant be in Perth or Pittsburgh? These issues are normally the proper do main of the senior management team., ${ }^{, 50}$ Furthermore, " $[\mathrm{t}]$ here is little or no court interference in enterprise issues," and "[s] tockholder involvement in enterprise issues is usually nonexistent. ${ }^{51}$ Enterprise issues are distinguished from "ownership issues," such as "should we merge our widget company with an automobile manufacturer and fend off unwanted suitors who wish to take control by a tender offer to the stockholders?" ${ }^{\text {"2 }}$

Enterprise decisions, and thus much of what we call corporate policy, falls within the protections of the business judgment rule. The rule establishes that as long as the directors were informed and disinterested when they made the decision and the decision was rational, it

\footnotetext{
${ }^{50}$ E. Norman Veasey, The Defining Tension in Corporate Governance in America, 52 BUS. LAW. 393, 394 (1997)

${ }^{51}$ Id.

${ }^{52} I d$. The distinction between enterprise and ownership issues first drawn by Bayless Manning, Reflections and Practical Tips on Life in the Boardroom After Van Gorkom, 41 BUS. LAW. 1 (1985), has found its way into Delaware case law. See, e.g., Loudon v. Archer-Daniels-Midland Co., 700 A.2d 135, 147 n.47 (Del. 1997) (drawing a distinction between enterprise and ownership decisions); ACE Ltd. v. Capital Re Corp., 747 A.2d 95, 105 (Del. Ch. 1999) (discussing the implications of the enterprise/ownership distinction for lockup agreements).
} 
cannot be challenged by shareholders. The rationale for the business judgment rule is to protect centralized management, one of the core features of the corporate form. ${ }^{53}$ It is statutorily enshrined in section 141 (a) of the Delaware General Corporation Law: "The business and affairs of every corporation ... shall be managed by or under the direction of a board of directors . ..., ${ }^{54}$

Although the distinction between enterprise and ownership issues is a useful categorization, those who have written on the distinction do not offer guidance on resolving the conflict between allowing for management discretion or shareholder choice when both enterprise and ownership issues are present. In the next Part, we develop a model that provides a way to resolve the conflict. Based on our model we conclude that management discretion should be allowed for when doing otherwise would materially compromise the ability or willingness of managers to use their own superior information to manage the business and affairs of the corporation.

\section{CORPORATE POLICY BY WELL-INFORMEd MANAGERS AND THE FIRM'S FUNDAMENTAL VALUE}

In what ways are financial markets informationally efficient and what are the implications of this efficiency? Academic finance scholars generally agree that empirical tests continue to provide support for the contention that no trading strategy involving public information can outperform the market, thus supporting the weak and semistrong forms of the Efficient Capital Markets Hypothesis (ECMH). However, the evidence does not support the strong form of ECMH, meaning that there can be periods when managers (broadly defined as including both directors and senior executives) have information superior to that of the market. Legal scholars, however, seem to be more attached to a view that implies strong form efficiency, namely that the market value of the firm is the only meaningful value of the firm.

Based on the financial economics literature, our argument reaches different implications than the prevailing legal literature. In our approach, the firm's intrinsic value differs from the firm's market value because we assume that managers know more than the market about the fundamental value of the firm's assets associated with each

\footnotetext{
${ }^{59}$ See Rock \& Wachter, supra note 46, at 1667 (finding that the business judgment rule is, among other things, about "maintaining centralized management").

${ }^{54}$ DEL. CODE ANN. tit. 8, §141(a) (2001).
} 
possible capital expenditure choice. We also assume that managers are unable to credibly and verifiably disclose their privileged information to the market. Hence, the market and the managers may have different estimates of the value of the corporation. This is a violation of what is commonly called "strong form efficiency," and as mentioned above, it is an important assumption of our approach.

The second assumption on which our approach is founded is the importance of managerial independence in setting corporate policy. In our view, this independence becomes critically important when the managers' corporate policy choice is based on information that the market does not possess. ${ }^{55}$ In such a circumstance, the managers' use of privileged information in setting corporate policy is a source of potential value creation for the firm. If the managers were forced to formulate corporate policy without superior information, their uninformed choice would result in a lower firm value. The value created, on average, for shareholders by the managers' ability to use their superior information in formulating corporate policy is analogous to the value of a financial option. In effect, the managers have the option to use privileged information when they choose a level of capital expenditure and their use of this option creates value.

The process by which managers create value by using superior information to set corporate policy is developed formally in the context of the model, but its essence can be understood by considering how the managers' corporate policy choice responds to good news or bad news such as changes in product market conditions. When managers receive good news, their policy choice response is typically more aggressive and implies a higher level of capital expenditure that enhances firm value above what it would be if their choice had been made without the benefit of such news. This magnifies the impact of the good news on the firm's intrinsic value.

When managers are less optimistic about asset values than the market, they typically respond by being less aggressive in setting corporate policy, mandating lower levels of capital expenditure. The informed policy response to bad news raises the firm's value above what it would be if the policy choice were uninformed, but this normally only mitigates the impact of the bad news without eliminating it. Thus, in spite of management's best efforts to adapt policy to its

\footnotetext{
${ }^{55}$ This assumption is unremarkable and we know of no article that questions the necessity of having managers rather than shareholders conduct the business and affairs of the corporation. The implications of this assumption, however, are rarely explored in the takeover literature.
} 
private adverse information, the intrinsic value of the firm remains below the market value. On average, the managers' ability to use bad news to mitigate its impact and good news to magnify its impact raises the value of the firm above what it would be if the policy choice were uninformed.

This ability of informed managers to create value for shareholders is normally protected by the presumption of the business judgment rule. In the contested control context, however, the standard of review is Unocal/Unitrin because of the increased potential that managers may use management discretion to entrench themselves.

This brings us to the second element in our model. In particular, we describe how a shareholder choice regime can create the potential for an agency problem that has previously been unappreciated. This agency problem, managing to the market, arises when informed managers, who anticipate the possibility of a future hostile bid, choose to ignore their superior information in formulating corporate policy and manage using information believed to be true by the market. They do this to avoid the underpricing that would occur if the uninformed, outside investors observe managers choosing a policy that they believe to be nonoptimal. Avoiding this underpricing reduces the chance that a hostile bid will arise. For the purpose of developing this argument, we consider investment decisions made prior to the emergence of a bid. We also emphasize that this situation is one that occurs repeatedly.

In developing both of these themes, we assume that investors do not believe that managers are making informed decisions, where the term "informed decisions" means decisions that are based upon better information than that available to the market. In other words, investors believe that the managers and the financial markets are equally well informed; that is, they believe that strong form efficiency holds. A possible objection is that investors do believe that managers are making informed decisions because they learn (quickly) the managers' information and thus whether the manager is making correct decisions. To a point, this is true; investors might well believe that managers are making informed decisions. If the better information available to the manager is about options that he decides to pursue, the market will learn of it. However, if the better information is about options that he opportunistically ignores because it risks his position, the market does not learn that the manager failed to adopt a valuable policy. In this case, investors do not learn that the manager was better 
informed. We elaborate on this point in the context of the second model.

Agency costs of the traditional kind are ignored in the development of the first model, not because we regard them as unimportant, but because we want to use the model to develop our first theme simply and clearly. We agree with the view that a shareholder choice regime creates incentives for managers to reduce agency costs in order to raise the value of the firm and thereby discourage possible takeover bids. However, the arguments of the first model can be extended to the case in which agency costs of the traditional kind arise. Furthermore, the conclusions of the model continue to hold, albeit in slightly modified form, when these agency costs are considered.

\section{A. Does the Firm's Market Value Measure its Intrinsic Value?}

While the informational assumptions of our model violate the strong form of the ECMH, which asserts that securities prices reflect all of the information of all market participants, they are consistent with the semi-strong and weak forms of ECMH. In our terminology, financial markets are only relatively efficient and any mispricing disappears over time. This is quite different from the proposition in the Lipton and Rowe article. ${ }^{56}$

In our framework, it seems quite uncontroversial to refer to the managers' informed valuation as the firm's intrinsic value and to expect this value to differ from the market value. Our definition of the firm's intrinsic value conforms to the usage of the term in Delaware corporate jurisprudence. Corporate law states that directors bear the ultimate responsibility for managing the business and affairs of a corporation and must be informed as to the corporation's intrinsic value when making a decision regarding the sale of the company. ${ }^{57}$ In our discussion, this intrinsic value is represented by the DCF of the firm's assets, as determined by the informed managers. Financial markets are not strong form efficient, however, and the company's stock may be over- or underpriced at any point in time. In this context, asking the directors to use their arguably superior information to assess the value of the corporation makes sense. In the model described above

\footnotetext{
${ }^{56}$ See Lipton \& Rowe, supra note 23, at 23 (arguing that the efficient market theory is "fundamentally flawed").

${ }^{57}$ Smith v. Van Gorkom, 488 A.2d 858, 873 (Del. 1985) (discussing how directors must ascertain this value prior to submitting any decision to shareholders for approval).
} 
and developed below, we assume that managers do indeed have superior information and use it in the formulation of corporate policy.

In the preceding discussion, we have been vague about the nature of the managers' information. DCF calculations require knowledge of the firm's expected future cash flows and of the rate used for discounting those cash flows. It seems natural to assert that managers might well have better information than the market about the cash flows the corporation's assets are expected to generate, and that is, indeed, one case we consider. There is now a substantial body of literature on asymmetric information in financial markets in which this assumption is made. For example, Shleifer and Vishny used this assumption in an earlier paper on hostile takeovers. ${ }^{58}$ This assumption has also been made in Ross's debt signalling model ${ }^{59}$ and in several papers on dividend signalling, including one by Miller and Rock. ${ }^{60}$ It is also used in the financial signalling model of Leland and Pyle, ${ }^{61}$ as well as in the influential work of Myers and Majluf on the market impact of equity issues. ${ }^{62}$ The work of Grossman and Stiglitz also casts doubt on the theoretical foundations of the efficient market model and is consistent with "semi-strong" or weak form efficient markets. ${ }^{63}$

We will argue that the managers may also be better positioned than outside investors to know the discount rate appropriate for use in a DCF calculation of firm value. The important issue is how the risk

\footnotetext{
${ }^{58}$ See Andrei Shleifer \& Robert W. Vishny, Greenmail, White Knights, and Shareholders' Interest, 17 RAND J. ECON. 293, 295 (1986) (noting that a target's managers have private information which they reveal to the public by paying greenmail).

${ }^{59}$ See Stephen A. Ross, The Determination of Financial Structure: The IncentiveSignalling Approach, 8 BELL J. ECON, 23, 27-31 (1977) (developing a model that establishes a signalling equilibrium based on the assumption that managers have inside information).

${ }^{60}$ See Merton H. Miller \& Kevin Rock, Dividend Policy Under Asymmetric Information, 40 J. FIN. 1031, 1031 (1985) (arguing that "managers know more than outside investors about the true state of the firm's current earnings").

${ }^{61}$ See Hayne E. Leland \& David H. Pyle, Information Asymmetries, Financial Structure, and Financial Intermediation, 32 J. FIN. 371, 372 (1977) (noting that while an entrepreneur may not be able to directly convey inside information, she may be able to signal that information to potential shareholders based on the fraction of equity that she retains).

${ }^{62}$ See Stewart C. Myers \& Nicholas S. Majluf, Corporate Financing and Investment Decisions When Firms Have Information that Investors Do Not Have, 13 J. FIN. ECON. 187, 187 , 195-96 (1984).(basing an equilibrium model of the issue-invest decision, in part, on the assumption that management knows more about the firm's value and noting the difficulties in conveying that knowledge to shareholders).

${ }^{63}$ See Sanford J. Grossman \& Joseph F. Stiglitz, On the Impossibility of Informationally Efficient Markets, 70 AM. ECON. REV. 393, 404-05 (1980) (arguing that the cost of information prevents market prices from perfectly reflecting value).
} 
premium included in the discount rate is determined. The most common approach is to use the Capital Asset Pricing Model (CAPM) to obtain this premium. In applying the CAPM, the risk premium added to the risk free rate is obtained from the firm's "beta" $(\beta)$, a measure of the "systematic" risk of its assets. We begin our discussion by arguing that, because of the imprecision of the empirical measures of beta, the application of this approach introduces room for disagreement about the risk premium and hence about the discount rate appropriate for valuing the firm's assets. Indeed, Fama, who strongly supports market efficiency, has asserted that he believes that CAPM estimates of the market capitalization rate for individual companies are close to useless. ${ }^{64}$ Thus, there is considerable room for reasonable and informed managers and shareholders to disagree about the true discount rate. The following Section follows Wachter and develops the argument more fully.

\section{B. Why the Managers Might Know More About the Market Capitalization Rate}

It is now well documented that market estimates of $\beta$ are highly imprecise so that the market point estimate of $\beta$ has a wide confidence interval around it. Consequently, corporate valuations resulting from the use of imprecise $\beta$ 's are similarly imprecise. Fama and French have shown that uncertainty about the true asset-pricing model and uncertainty as to the coefficient values in each model lead to estimates of the cost of equity that are "distressingly imprecise." ${ }^{66}$ The impact of imprecise costs of capital will vary with the nature of

\footnotetext{
${ }^{64}$ See Eugene F. Fama \& Kenneth R. French, Industry Costs of Equity, 43 J. FIN. ECON. 153, 178 (1997) (concluding that there is uncertainty about the true asset pricing model and that estimates of the cost of equity are "distressingly imprecise"). Current views of market efficiency allow for deviations from efficiency that appear and are then arbitraged away. These returns, however, are still not "excess" returns, in the sense that arbitrage to bring prices in line with the predictions of CAPM are risky investments.

${ }^{65}$ See Wachter, supra note 10, at 792-93 (arguing that shareholder choice applies if financial markets are entirely efficient, but if financial markets are only relatively efficient, "management may be better informed than the market as to the correct market capitalization rate").

${ }_{66}^{66}$ Se Fama \& French, supra note 64, at 178 (stating that large standard errors of more than three percent per year are driven primarily by uncertainty about the true factor risk premiums).
} 
the business-being greatest in cases where the firm has long-lived capital-and will be quite large in most cases. ${ }^{67}$

This opens the door for a claim that the managers of a firm may have superior information as to the appropriate discount rate, and hence, may have a better estimate of the value of the corporation than does the market. Discount rates, after all, are project specific and a firm generally has any number of such projects. The ultimate source of a firm's market capitalization rate, $r$, is the collection of real assets and the covariance of the return those assets generate against economy-wide real assets. The more idiosyncratic the firm's real projects, the more likely the managers will have superior information about the systematic covariance between the asset's cash flow, $C F$, and economy-wide cash flow.

The case-study evidence on how firms actually make investment decisions strongly suggests that they do not act as assumed in the textbook model, where $\beta$ is perfectly known, but rather act as might be expected from the empirical evidence. Instead of using the market's estimate of its $\beta$, firms adopt various sensitivity tests of an investment based on alternative discount rates. Included in this are the firm's own estimates of the systematic risk of individual projects.

The upshot is that we assume that the managers of the corporation have an estimate of $\beta$ that is based on their own information and that that information is reasonably reliable. The financial market, on the other hand, generates a distribution of $\beta$ 's that are believed by the market, but only weakly so. One can think of the market as drawing a $\beta$ from a distribution that yields a market valuation. The valuation, however, can vary over a wide range depending on the particular draw. From time to time, the market's valuation will equal the managers' own valuation, but there is no reason to assume the two are

${ }^{67}$ A reasonable question in the corporate law context is whether the confidence intervals around the market value of the corporation are wider than the average premium bid in a hostile tender offer. If the confidence interval is $20 \%$ on either side, for example, then a traditional tender offer with a $30 \%$ premium would still give a court attempting to use an intermediate standard of judicial scrutiny reason to believe that the offer is above the intrinsic value of the corporation. Unfortunately, that does not appear to be the case, although more information is needed to say anything definitive. The standard errors reported by Fama and French indicate that confidence intervals around the value of the corporation could require more than a $100 \%$ premium, or even more in some cases, to land outside of the $95 \%$ confidence interval. Id. at I77. It is possible, however, that changes in the discount rate are correlated with changes in the growth rate of the future cash flows. If, for example, increases in systematic volatility are associated with faster growth rates in cash flow, changes in the growth rate would, at least in part, offset changes in the discount rate. 
the same at any point in time. The assumption we make in this Article is that the firm and the market agree on the probability distribution of $r$, but the firm has more precise information as to its true value.

The discrepancy disappears if the firm can communicate its private information to the market. However, that is no easy task. This issue highlights our reason for believing that the financial market and the managers are more likely to agree on cash flow estimates than they are on estimates of the discount rate. Estimates of cash flow are the mean return on the assets; that is, the first moment of the probability function of the cash flow. Because the firm is known to have information advantages as to the mean return, the market is likely to accept the guidance provided by the managers, at least to a certain extent. Estimates of the discount rate are a component of the second moment of the probability distribution; that is, the covariance of the cash flows generated by the assets against the cash flow of the economy's real assets. Presumably information about a piece of the second moment of a probability distribution is more difficult to communicate in a verifiable way than information about the first moment. Similarly, because the market automatically generates its own estimate of $\beta$ from the trading history of the stock, it may be unwilling to take any guidance the firm might offer as to the set of $\beta$ 's on the firm's set of real assets.

\section{A FIRST MODEL OF CORPORATE POLICY: INTRODUCTION TO THE FORMAL MODEL}

As noted earlier, we follow Hart and others, and view the corporation as the collection of assets over which it has rights of residual control. $^{69}$ Stripping the firm down to its core, we assume it has a collection of existing assets that are expected to generate a stream of future cash flows. We also assume that the firm has cash assets that can be used by the firm's management to make new investments that are expected to add to the stream of future cash flows. We use $I$ to denote the level of new investment or capital expenditure which we take to be the most critical variable in a corporation's strategic planning program. The firm has cash, $C$, on hand and the managers use some of this cash when they invest $I$. To simplify the discussion, we assume that the firm's cash flows, $C F$, grow at a constant rate of growth into the future, denoted as $g$. In the first period after the investment

\footnotetext{
${ }^{68}$ See supra text accompanying note 46.
} 
level, $I$, has been chosen the firm's expected cash flows are determined by the investment decision and equal $C F(I)$.

After $t$ periods, the firm's cash flows are expected to have grown to $C F(I)(1+g)^{\prime}$. We also assume that $C F^{\prime}(I)>0$ and that $C F^{\prime \prime}(I)<0$. Note that in this formulation of the problem we are assuming that the choice of $I$ has no impact on $g$. When the firm invests more, the stream of cash flows is simply shifted upward and the cash flow in every period is scaled up by a common factor. We could easily extend the analysis to include the case in which the growth rate also increases with the level of investment. In order to simplify the discussion, however, we have chosen not to do so.

We interpret $C F(I)$ as the sum of $C F_{P}+C F_{N}(I)$, where $C F_{P}$ are the cash flows obtained from the firm's previous investments and $C F_{N}(I)$ are the cash flows obtained as a result of the new investments, $I$. Note that $C F_{P}$ are independent of the level of the current investments and are a legacy of the firm's previous investments.

For simplicity, we assume that the same discount rate, $r$, is appropriate for discounting the cash flows from both old and new investments. Also, we simplify the discussion by assuming that the firm is entirely equity financed, making the introduction of debt financing irrelevant to our argument.

These assumptions combine to enable us to use the Gordon Growth Model ${ }^{69}$ to calculate the fundamental value of the corporation associated with the investment level $I$ :

$$
C-I+\frac{C F(I)}{r-g}
$$

In determining the discount rate, $r$, we use the CAPM, which is the most widely used asset pricing theory when adjusting for risk. Thus, to obtain the discount rate we add the familiar risk premium $\beta\left(r_{m}-r_{f}\right)$ to the risk free rate. The discount rate used to value the firm is then simply $r=r_{f}+\beta\left(r_{m}-r_{f}\right)$ where $r_{f}=$ the risk-free rate, $r_{m}=$ the return on the market portfolio, and $\beta=$ the covariance of the return to the firm's investments with the market return. Because we assume that the firm has no debt, there is no need to adjust the discount rate to reflect the firm's capital structure. The value of the corporation depends on the initial cash flow, the growth rate, $g$, and

\footnotetext{
${ }^{69}$ See Myron J. Gordon, INVESTMENT, Financing, AND VALUATION OF THE COR-
} PORATION 45 (1962) (presenting a stock valuation model). 
the discount factor, $r$, so that differences in valuation can arise from any of these sources. The term $r$ is often referred to as the corporation's market capitalization rate and we will use this term below.

The position we develop as to the source of any discrepancy in valuation between managers and the market differs from the traditional position, which typically assumes that the firm has private information about the growth rate or the level of its expected cash flows. Our formal analysis will, as noted earlier, follow Wachter and assume that a main source of disagreement will be the firm's $\beta$ and hence its market capitalization rate. None of the legal implications of our analysis, however, turn on whether valuation disagreements arise from different assessments of $C F(I), g$, or $r$. To keep the Article as general as possible, we therefore model the firm's investment decision in terms of a discount factor. Consequently, instead of working with $r$, thus excluding the possibility that the managers and the market may disagree about $g$, we will proceed formally by working directly with the discount factor

$$
\delta=\frac{1}{r-g} .
$$

Thus, our model assumes that the managers know $\delta$ while the market does not.

\section{A. Value Creation by Informed Management}

In our model, we focus on the firm's corporate policy as it applies to its investment or capital expenditure decisions. The firm's fundamental value, which we denote by $V$, is related to the level of new investment, $I$ as follows:

$$
V=C-I+\delta C F(I) \text {. }
$$

As stated earlier, the firm's cash flows include those generated by its existing assets as well as by its new investment.

It is clear from this expression that the firm's value depends not only on the level of investment but also on the discount factor. We emphasize that the level of investment that maximizes the value of the firm also depends on the discount factor. In particular, the higher the discount factor, the higher the optimal investment will be. The reason is simply that incremental investments yield expected future cash flows with higher present values when the discount factor $\delta$ is higher. This means that it is crucial for the managers to know $\delta$ if they are to be able to make a correct corporate policy decision. 
We use $V(\delta)$ to denote the value of the firm when investment is at its optimal level. This is what we call the maximum enterprise value of the firm. Formally,

$$
V(\delta)=C-I(\delta)+\delta C F(I(\delta))
$$

If the investment level is always optimally chosen to be $I(\delta)$, the discount factor $\delta$ affects the firm's value, both directly, and indirectly through its impact on investment. The managers adopt what we call a value-creating corporate policy when they respond to any change in the discount factor by maximizing the fundamental value of the firm. Note that an increase (decrease) in the discount factor increases (decreases) not only the value of the existing capital but also of new investments. When the discount factor $\delta$ falls, the resulting reduction in the investment level helps to mitigate the impact of the reduction in the present value of the future cash flows. As a consequence, although $V(\delta)$ does fall when $\delta$ falls, the maximum enterprise value of the firm does not fall as much as the firm's enterprise value would if the investment level was not reduced in response to the decrease in $\delta$. When the discount factor $\delta$ rises, the resulting increase in the investment level enhances the impact of the rise in the present value of the future cash flows. Consequently, when $\delta$ rises, the maximum enterprise value of the firm, $V(\delta)$, also rises and indeed rises by more than it would if the investment level did not also increase with the increase in $\delta$.

In our model, we assume that there are no agency costs. The managers use their knowledge of $\delta$ to choose an optimal corporate policy that is implemented by investing the amount $I(\delta)$ that maximizes the firm's net present value (NPV). This is entirely consistent with the interests of the shareholders and implies that the value of the firm to the shareholders is its intrinsic value $V(\delta)$.

We now turn to a formal description of the market value of the firm. For the reasons given earlier, we assume that the market investors know less than the managers. In particular, we assume that the managers know, and that the market does not know, $\delta$. We have defined the intrinsic value of the firm to be $V(\delta)$-the fundamental value of the firm when the managers use their privileged information about the discount factor to choose an optimal corporate policy by investing $I(\delta)$. Although the market does not know $\delta$, it does have beliefs about it and we view the market as treating the discount factor as the realization of a random variable $\widetilde{\delta}$. The market's expected discount factor is $\bar{\delta}=E \widetilde{\delta}$. 
We assume that before the managers learn $\delta$, they have the same beliefs about it as the market. When the market believes that the managers do not know the discount factor and expect it to be $\bar{\delta}$, the market also believes that the managers choose to maximize the expected fundamental value of the firm by investing $I(\bar{\delta})$. The market value of the firm will then be $V(\bar{\delta})$.

It will be convenient to have a shorthand way of referring to the case in which the investment level actually is $I(\bar{\delta})$. If the managers were to choose to invest $I(\bar{\delta})$, we will say that they are "managing to the market." Thus:

Value of the firm when managed to the market $=V(\bar{\delta})$.

In the context of our model, the company's stock may be over- or underpriced at any point in time. It is underpriced when the managers know that its intrinsic value exceeds its market value; i.e., when $V(\delta)>V(\bar{\delta})$. It is also possible that the managers can know that the firm is overpriced by market value because they know that $V(\delta)<V(\bar{\delta})$. On average, the market undervalues the firm because $E V(\widetilde{\delta})>V(\bar{\delta})$. The value created when informed managers use their information to improve their investment decisions is $E V(\widetilde{\delta})-V(\bar{\delta})$.

\section{B. The Uninvited Tender Offer}

In this Section, we analyze how a current-period investment decision is affected by the emergence of a hostile bidder. We start by assuming that an uninvited bid for the company is made public before the current-period investment decision has been finalized. We note that this case includes the situation, which appears to be quite common, where a bidder emerges well before the bidder's existence becomes known publicly because the bidder and managers have already engaged in exploratory discussions about a possible control transaction. When the bidder arrives, the firm's market value is $V(\bar{\delta})$.

As part of her due diligence, the bidder arrives with some news about $\delta$ but she does not know its exact value. ${ }^{70}$ We assume that the bidder knows more than the market but not as much as the managers. ${ }^{71}$ The case of interest is that in which the bidder is more

\footnotetext{
${ }^{70}$ We assume that before the bidder receives her news about the $\delta$ she has the same expected discount factor $\bar{\delta}$ as the market.

${ }_{71}$ The assumption that the bidder knows more than the market is the traditional assumption. See Sanford J. Grossman \& Oliver D. Hart, The Allocational Role of Takeover Bids in Situations of Asymmetric Information, 36 J. FIN. 253, 255 (1981) (stating that while
} 
optimistic about the value of the firm than the market and is thus willing to bid for the firm.

Conditional on the specific nature of the news, $n_{b}$, received by the bidder, the expected discount factor is $\bar{\delta}\left(n_{b}\right)=E\left[\widetilde{\delta} \mid n_{b}\right] .^{72}$

We assume that the bidder intends to replace existing management and that she is therefore unable to take advantage of her knowledge of the discount factor $\delta$. The bidder will then be forced to rely on her own information in setting corporate policy. In that case, the bidder will choose the investment level $I\left(\bar{\delta}\left(n_{b}\right)\right)$, which maximizes the expected fundamental value of the firm, $\left(C-I+\bar{\delta}\left(n_{b}\right) C F(I)\right)$, which is computed using its conditional expectation of the discount factor. Accordingly, for the bidder, the value of the firm is $V\left(\bar{\delta}\left(n_{b}\right)\right)=\left(C-I\left(\bar{\delta}\left(n_{b}\right)\right)+\bar{\delta}\left(n_{b}\right) C F\left(I\left(\bar{\delta}\left(n_{b}\right)\right)\right)\right)$. To simplify the model-and since nothing turns on the issue-we assume that the bidder always bids her true valuation for the firm.

Assume first that the managers are more optimistic than the bidder. In that case, $V(\delta)>V\left(\bar{\delta}\left(n_{b}\right)\right)$. The manager's response to the bid will depend on whether the legal regime is shareholder choice or management discretion. If the shareholder choice rule applies, the managers know that they will eventually be forced to sell and the company will be sold for $V\left(\bar{\delta}\left(n_{b}\right)\right)$.

Suppose now that the management discretion rule applies and management can successfully resist the takeover attempt if it chooses. In this case, the management will resist the bid, remain in control of the firm, and continue to use its information about $\delta$ by investing $I(\delta)$, which exceeds $I\left(\delta\left(n_{b}\right)\right)$.

The shareholders may be disappointed when the managers do not accept the bid, since the bid is above the market value. However, when the market eventually learns the true discount factor, the market value of the firm will rise above the bid level to the true or intrinsic price, $V(\delta)$. Thus, in a world without agency costs, the shareholders are best off when the managers use their private information to maximize the value of the firm since that value accrues to the

some information about a firm or its management is unavailable to the public due to high investigation costs, a bidder will acquire such information because she can productively use that information); Shleifer \& Vishny, supra note 58, passim (analyzing methods by which to promote information acquisition by potential bidders).

${ }^{72}$ Note also that the market's unconditional expectation of the discount factor equals the expectation of the bidder's conditional expectation. In other words, we must have $\bar{\delta}=E_{n b}\left[\bar{\delta}\left(\tilde{n}_{b}\right)\right]$. 
shareholders. If the shareholders knew what their fiduciaries know, they would not want the firm sold at the bid price.

Now we analyze the case where the bidder is more optimistic than the managers, $V\left(\bar{\delta}\left(n_{b}\right)\right)>V(\delta)$. In this case, the outcome does not depend on which legal rule is in force. In a shareholder choice regime, the managers sell the firm to the bidder because the bid is above the market price. This result is independent of whether the bidder is more or less optimistic than the managers. Meanwhile, if the management discretion rule applies, the managers will still approve the merger. This is true because they know that even if they make the optimal investment decision, $I(\delta)$, the true value of the firm, $V(\delta)$, will be lower than the bid $V\left(\bar{\delta}\left(n_{b}\right)\right)$. Consequently, the managers will not say no, even if they can.

After the bidder buys the firm, she will learn that the cash flows from the firm's assets have a lower present value than she had expected, as the true discount factor is only $\delta$. As a result, her valuation of the firm will fall from

$$
V\left(\bar{\delta}\left(n_{b}\right)\right) \text { to } C-I\left(\bar{\delta}\left(n_{b}\right)\right)+\delta C F\left(I\left(\bar{\delta}\left(n_{b}\right)\right)\right) .
$$

In fact, there is a double dose of bad news. Not only are the cash flows across all assets lower than she had anticipated, but also the capital expenditure level, $I\left(\bar{\delta}\left(n_{b}\right)\right)$, represents an overinvestment. If the investment level had been $I(\delta)$, the bidder's loss would have been only $V\left(\bar{\delta}\left(n_{b}\right)\right)-V(\delta)$, which is the shareholders' gain from having sold an overvalued firm.

\section{A MOdEL OF CORPoRAte ChOICE WTTH A NEW TyPe OF AgENCY COST}

\section{A. The Formal Model}

In this second model, we allow for agency costs of a particular kind. As is traditionally the case, managers may seek to entrench themselves. What changes, though, is the strategy of the managers. In most of the literature, managers entrench themselves by deploying takeover defenses and ignoring the financial market when a hostile bid emerges. Although this is an effective takeover defense in many cases, there is a potentially more effective strategy: adopt a corporate policy that minimizes the potential of a takeover bid from emerging. This is available in regimes where financial mispricing occurs; the corporation can protect itself by paying heed to the financial market while ignoring its own private information. 
economy investment is known to the managers, it is not known to the market. Thus, for the managers, the value of the old economy investment is $\delta_{o} C F_{o}$, where

$$
\delta_{o}=\frac{1}{r_{o}-g_{o}} .
$$

In this scenario, the firm's value depends on the investment choice and the discount factors for both the new and the old economy investments. However, the high tech discount factor appropriate for discounting the investment is known to all and, for that reason, its effect need not be explicitly considered.

We assume that the old economy investment is the optimal choice and that the true discount factor, $\delta_{o}$, is sufficiently high so that $\delta_{o} C F_{o}>\delta_{h} C F_{h}$. We use $V\left(\delta_{o}\right)$ to refer to the value of the firm when the investment is optimally chosen.

While the market does not know $\delta_{o}$, it has beliefs about $\delta_{o}$, and we view the market as treating the discount rate as the realization of a random variable $\widetilde{\delta}_{o}$. The market's expected discount factor is $\bar{\delta}_{o}=E \widetilde{\delta}_{o}$. Once again, we assume that before the managers learn $\delta_{o}$, they have the same beliefs about it as the market.

Recall that we are assuming that the market knows whether the managers have made the high tech or old economy investment. If the managers make the old economy investment, the market values the firm at $\bar{\delta}_{o} C F_{o}$. If the managers make the high tech investment, the market values the firm at $\delta_{h} C F_{h}$.

In this second model, the case of primary interest arises when the managers are more optimistic about the old economy investment than the market. Formally, this case arises when $\delta_{o}$, the managers' old economy discount factor, exceeds $\bar{\delta}_{o}$. In fact, we assume that this difference of opinion is so strong that it leads to a disagreement about the correct investment choice between the managers and the market. Formally, we assume that $\delta_{o} C F_{o}>\delta_{h} C F_{h}>\bar{\delta}_{o} C F_{o}$. In this case, the managers know that the shareholders should prefer the old economy investment because its value, $\delta_{o} C F_{o}$ exceeds the value of the high tech investment, $\delta_{h} C F_{h}$. Since the managers have the best information, the correct investment decision is the one they know the shareholders should prefer. In the present case, that is the old economy investment and the true value of the firm is $V\left(\delta_{o}\right)=\delta_{o} C F_{o}$. 
We pose the model in the following context. The corporation has a choice between two distinct types of investments. One of these will be referred to as a "high tech" investment, while the other possibility is an "old economy" investment. We assume that these technologies are mutually exclusive, so the firm can choose one, but not both. For the purpose of this discussion, we change the timing of the investment decision and assume that it is made before any bid emerges. Because the market and any potential bidders observe this investment choice, the managers know there will be a market reaction. As before, the market does not know that the managers are better informed, so it continues to prefer that the managers adopt the market's preferred corporate policy.

The managers recognize that the firm's market value will be adversely affected if they choose an investment policy that differs from the one preferred by less well informed investors in the market. They therefore have a choice. On one hand, they can make the investment decision that they believe to be correct, even if the immediate result is a lower stock price and an increased risk of a hostile tender offer. Alternatively, they can choose to adopt the market's information set, thus managing to the market, with the immediate result of a higher stock price and a reduced risk of a hostile tender offer.

The consequences of this decision differ significantly under shareholder choice and management discretion rules. In a shareholder choice regime, managers are vulnerable to a hostile tender offer and therefore, if they wish to retain their jobs, may manage to the market in order to reduce the likelihood of a bid emerging. In a management discretion regime, managers can reject a hostile tender and are therefore less vulnerable to a low stock price. They are therefore more likely to act on their own, better-informed information.

In this model, we assume that for the high tech investment, the discount factor is $\delta_{h}$, and the first period cash flow is $C F_{h}$. The growth rate for the high tech investment is known to the market, the managers, and the bidder. Since we ignore the investment level, the value of the firm when it makes the high tech investment is $\delta_{h} C F_{h}$, where

$$
\delta_{h}=\frac{1}{r_{h}-g_{h}} .
$$

The first-period cash flow $C F_{o}$ and the growth rate for the old economy investment are also known to the market, the managers, and the bidder. Critically, although the discount factor, $\delta_{o}$, for the old 
If, however, the managers manage to the market and they choose the high tech investment, the market value of the firm is $V\left(\bar{\delta}_{o}\right)=\delta_{h} C F_{h}$, and the firm is undervalued.

In this model the bidder is considering making a bid for the company (rather than having already made a bid, which is the assumption in the prior model).$^{73}$ As before, we suppose that any bidder that does emerge will have some news about $\delta$, but will not know its exact value. Thus, once again, we assume that the bidder will know more than the market, but not as much as the manager. The only case of interest is that in which the potential bidder is more optimistic about the value of the firm than the market, and is thus willing to bid for the firm.

Conditional on the specific nature of the news, $n_{b}$, received by the bidder, the expected discount factor is $\bar{\delta}_{o}\left(n_{b}\right)=E\left[\widetilde{\delta}_{o} \mid n_{b}\right]$. The bidder values the old economy investment using the expected discount factor $\bar{\delta}_{o}\left(n_{b}\right)$. She thus values the old economy investment at $\bar{\delta}_{o}\left(n_{b}\right) C F_{o}$.

Consider the case where the managers are more optimistic about the old economy investment than the bidder, who is, in turn, more optimistic about that investment than the market. This case arises when $\delta_{o}$, the true old economy discount factor of the managers, exceeds $\bar{\delta}_{o}\left(n_{b}\right)$, the expected old economy discount factor of the bidder. That, in turn, exceeds $\bar{\delta}_{o}$, the market's expected old economy discount factor. We suppose that, in spite of this difference of opinion between the managers and bidder, they agree about the correct investment strategy, which means that both disagree with the market. For both the managers and the bidder, the value of the old economy investment exceeds the value of the high tech investment. Formally, this situation is represented as $\delta_{o} C F_{o}>\bar{\delta}_{o}\left(n_{b}\right) C F_{o}>\delta_{h} C F_{h}$. The market's pessimism about the old economy discount factor leads investors to the conclusion that the high tech investment is preferable. Formally, $\delta_{h} C F_{h}>\bar{\delta}_{o} C F_{o}$.

Since the managers have the best information, the correct investment decision is the one they know the shareholder should prefer. In the present case, that is the old economy investment, which means the true value of the firm is $V\left(\delta_{o}\right)=\delta_{o} C F_{o}$. If in this situation the managers have managed to the market by choosing to make the high tech investment, the market value of the firm will be $V\left(\bar{\delta}_{o}\right)=\delta_{h} C F_{h}$.

\footnotetext{
${ }^{79}$ We again assume that before the bidder receives her news about the $\delta\left(r_{o}\right)$, she has the same expected discount factor, $\bar{\delta}$, as the market.
} 
Once this decision has been made, the market value of the firm is correct. Although the firm is valued correctly by the market, it is undervalued compared to the value it could have achieved had the correct investment been made. However, since the firm is no longer undervalued by the market, there is no reason for the bidder to bid. In other words, by managing to the market mispricing, the managers have adopted an effective takeover defense in that the bidder is now discouraged from making a bid. As a result, the managers retain control.

If the managers had made the correct decision to invest in the old economy technology, the firm would be undervalued by the market. The bidder would value the firm at $\bar{\delta}_{o}\left(n_{b}\right) C F_{o}$, and thus be willing to pay a premium over the market. (The bidder would therefore make the bid, but because the bidder is less optimistic than the managers and bids its valuation, the bid would still undervalue the firm.)

\section{B. Results of the Model}

We have shown that under the shareholder choice rule, managers who wanted to retain control would choose to manage to the market so as to discourage the bid. If the management discretion rule was in force, managers with the same motivation would make the correct choice, choosing the old economy technology and simply rejecting the bid when it arrived. This assumes that, even when there are agency costs, the managers can maximize their private benefits by maximizing the value of the corporation and then extracting their private benefits from the highest total valuation possible.

The agency problem we have just discussed is one that we view as potentially occurring in every period when market mispricing is present. This means that the managers may repeatedly choose to make decisions they know to be incorrect because they are motivated by a desire to retain control by raising the firm's market value and thereby discouraging bidders. Over time, the accumulated impact of such repeated mismanagement, caused by the incentives created by the shareholder choice rule, can significantly reduce the firm's value.

The implications of this observation are important. In a shareholder choice rule, the investor always gets to pocket the premium bid offered by the bidder. But the shareholder may be getting a premium bid off a market value that is too low because of the series of inappropriate investments made by the faithless managers who want to discourage a bid in every period. Under management discretion, the managers make decisions that the shareholders initially view 
unfavorably, possibly including the decision to reject hostile bids at a premium to the market. However, the initially unpopular decisions ultimately raise the value of the firm once the market learns what the managers knew earlier and recognizes the wisdom of the managers' corporate policy decisions. ${ }^{74}$

Finally, we offer a justification for the assumption that investors are unaware of the extent to which managers are better informed than the market, an assumption critical to our critique of the shareholder choice rule. Under that rule, the manager has an incentive to choose the high tech investment, which is the choice that investors favor and believe that the manager is making because it is most profitable. However, in our model, while the manager makes the high tech choice, it does so knowing that that is the inferior choice. Because the old economy investment is never made, the market never learns that this investment is as good as the managers know it to be. As a result, the market never learns that the managers are better informed and have made an incorrect decision.

Ironically, in the second model the market is strong form efficient in that the firm is correctly valued. Even so, investors are ignorant that the managers avoided making a superior investment choice in order to do what investors thought they should do. In reality, the firm is undervalued in comparison to what it would be worth under the management discretion rule.

\section{INTERPRETING DELAWARE CASE LAW IN THE CORPORATE POLICY MODEL}

Our claim is that the corporate policy model explains key elements of takeover law doctrine. In this Part, we show how the model explains the major Delaware Supreme Court cases including Unocal, $^{75}$ Revlon, ${ }^{76}$ Time-Warner, ${ }^{77}$ and $Q V C,{ }^{78}$ as well as the supreme court's rejection of the chancery court's Interco line of cases. We focus

${ }^{74}$ In Lucian Ayre Bebchuk \& Lars A. Stole, Do Short-Term Objectives Lead to Under- or Overinvestment in Long-Term Projects, 48 J. FIN. 719 (1993), Bebchuk and Stole develop a model that also stresses managerial investment decisions in the presence of imperfect financial market information, and in which management may pursue short-term objectives. They conclude, as do we, that the result can be either over- or underinvestment.

${ }^{75}$ Unocal Corp. v. Mesa Petroleum Co., 493 A.2d 946 (Del. 1985).

${ }^{76}$ Revlon, Inc. v. MacAndrews \& Forbes Holdings, Inc., 506 A.2d 173 (Del. 1986).

${ }^{77}$ Paramount Communications, Inc. v. Time, Inc., 571 A.2d 1140 (Del, 1989).

${ }^{78}$ Paramount Communications, Inc. v. QVC Network, Inc., 637 A.2d 34, 43 (Del. 1994). 
on Time-Warner as the watershed case in the evolution of the management discretion position. We do not claim that the model explains all aspects of the law or the current issues under debate.

Unocal was the initial decision that provided for intermediate scrutiny in cases where management uses takeover defenses to defeat a hostile tender offer. ${ }^{79}$ In this case, the Delaware Supreme Court's reasoning comports with the corporate policy model developed above. First, the court noted that the board's power to act to defeat a hostile tender offer flows from the board's obligation to "protect the corporate enterprise, which includes stockholders, from harm." ${ }^{, 80}$ Decisions made to protect the corporate enterprise are traditionally accorded the presumption of the business judgment rule. ${ }^{81}$ But in cases involving hostile tender offers there is an "omnipresent specter that a board may be acting primarily in its own interests, rather than those of the corporation and its shareholders. ${ }^{\text {"82 }}$ Cases such as these require that the target board satisfy a two-pronged inquiry. First, the target board must show that the hostile tender offer poses a threat to the corporation and its shareholders. Next, the court must be satisfied that the target board's response is proportional to the threat. ${ }^{83}$

The court's frequent references to the board's duties to protect the corporate enterprise (encompassing the duty to protect shareholders' interests) conform to our corporate policy model. If the board is using superior information when formulating corporate policy, it needs to have the power to implement the policy in order to recognize for shareholders the "value enhancing" investments that only those with private information can achieve.

For our purposes, we divide the application of the Unocal test into two distinct periods, pre- and post-Time-Warner. Shareholder choice enjoyed its heyday in the period between Unocal and Time-Warner. During this period, the chancery court developed the case law which has been referred to in the corporate law literature as the Interco line

${ }^{79} 493$ A.2d at 949 .

Id at 954 .

${ }^{81}$ See Aronson v. Lewis, 473 A.2d 805, 812 (Del. 1984) (describing the business judgment rule as the "presumption that in making a business decision the directors of a corporation acted on an informed basis, in good faith and in the honest belief that the action taken was in the best interests of the company").

${ }^{82}$ Unocal, 493 A.2d at 954.

83 Id. at 955 . The court states there must be an element of balance. "A corporation does not have unbridled discretion to defeat any perceived threat by any Draconian means available." Id. 
of cases. ${ }^{84}$ We interpret the shareholder choice position to be consistent with the Interco cases and favoring a broad application of Revlon duties.

\section{A. Interco and Revlon: When Shareholders Should Decide}

The Delaware Chancery Court developed Interco and applied it to the rash of hostile tender offers that occurred in the years immediately after Unocal. In analyzing the chancery court's rationale in Interco, we consider why that court gravitated to a set of holdings that provided shareholders with the power to ultimately decide the fate of hostile tender offers. We believe that the answer turns on the particular defensive strategies or corporate policies that target boards adopted in response to the hostile tender offers.

In a series of important cases from 1986 through 1989, the target board's response was to implement a financial restructuring that was intended to offer shareholders a better deal than was being offered by the bidder. ${ }^{85}$ This type of corporate policy response, however, meant that the original corporate policy that the board favored prior to the hostile bid was abandoned. As a result, the question of which deal (the restructuring or the bid) offered the most gain to shareholders was answered depending on how the financial market would price the particular financial instruments being offered. While target management could claim that it had superior information with regard to its initial corporate policy, it could not make this claim credibly once that policy was abandoned and replaced by a financial restructuring.

\footnotetext{
${ }^{84}$ See Gilson, supra note 2, at 497-500 (discussing the development of the Interco line of cases and its subsequent rejection by the Delaware Supreme Court).

${ }^{85}$ See Ivanhoe Partmers v. Newmont Mining Corp., 535 A.2d 1334, 1336-37 (Del. 1987) (noting that Newmont Mining proposed a financial restructuring that included a deal with its major stockholder in response to a hostile tender offer); Shamrock Holdings, Inc. v. Polaroid Corp., 559 A.2d 278, 281 (Del Ch. 1989) (explaining Polaroid's proposed financing restructuring built around an employee stock ownership plan); Grand Metro. Pub. Ltd. v. Pillsbury Co., 558 A.2d 1049, 1057 (Del. Ch. 1988) (detailing the Pillsbury board's proposed financial restructuring, designed to offer shareholders a higher-valued deal than that proposed by Grand Met); Nomad Acquisition Corp. v. Damon Corp., Nos. 10173 \& 10189, 1988 Del. Ch. LEXIS 133, at *3 (Del. Ch. Sept. 20, 1988) (stating that Damon's board met with legal and financial advisors to consider restructuring and use of their poison pill); Robert M. Bass Group, Inc. v. Evans, 552 A.2d 1227, 1230 (Del. Ch. 1988) (describing how the target board of Macmillan proposed an ESOP financial restructuring); AC Acquisitions Corp. v. Anderson, Clayton, \& Co., 519 A.2d 103, 104 (Del. Ch. 1986) (noting that Anderson, Clayton responded to a hostile offer with a self-tender for sixty-five percent of its outstanding stock).
} 
The facts of City Capital Associates v. Interco, Inc. ${ }^{86}$ are sufficiently instructive for our purposes to warrant attention. Interco was an oldstyle conglomerate with business conducted through a large number of independent, wholly owned, and independently operated subsidiaries. ${ }^{87}$ These conglomerates were a favorite target of corporate raiders in the 1980s and, for Interco, the raiders or hostile bidders were the Rales brothers. With Interco shares trading in the low $\$ 40$ s, the brothers first offered $\$ 64$ in cash for all the shares and then quickly upped their bid to $\$ 70$ per share, contingent on certain conditions, including the redemption of a poison pill. After the Interco board rejected this offer, the Rales brothers raised their bid again, to $\$ 72$ per share. ${ }^{88}$

The Interco board decided to defend against the all-cash hostile tender offer by pursuing a financial restructuring of the corporation. The restructuring included paying a large cash dividend, putting an important division up for sale, and selling a substantial amount of subordinated debt. ${ }^{89}$ After the restructuring, shareholders were to be left holding a "stub" representing the remaining value of Interco's assets in a highly leveraged state. Interco valued the restructuring deal at at least $\$ 76$ per share, including the proposed dividend and the remaining value of the highly-leveraged stub. The market placed a slightly lower value on the deal, and Interco's stock price did not trade above $\$ 70$ per share subsequent to the announcement of the restructuring. The Rales brothers then offered $\$ 74$ per share and appealed to the chancery court to force the redemption of the poison pill and block the recapitalization as an impermissible takeover defense. ${ }^{90}$

Applying Unocal, the chancery court reasoned that a threat to the shareholders originally existed and that Interco's board of directors could have reasonably believed that the original bid was "inadequate" (i.e., below the fundamental or intrinsic value of the corporation). ${ }^{91}$ In acknowledging inadequate value as a defense, the court clearly allowed for some degree of financial market pricing inefficiency. If

\footnotetext{
${ }^{86} 551$ A.2d 787 (Del. Ch. 1988).

${ }^{87}$ Interco was a holding company with twenty-one subsidiaries in four major business areas, each of which operated as an autonomous unit. Interco viewed itself as a "portfolio of assets" rather than an integrated whole. Id. at 791.

${ }^{88}$ Id. at 791-93.

${ }^{89}$ Id. at 794 .

90 $I d$, at $793-94$.

${ }^{91} I d$. at 798 .
} 
financial markets were entirely efficient, no bid above the market price could be below the fair value of the corporation.

Chancellor Allen then ruled that the threat to the shareholders in the form of inadequate value had been largely eliminated by Interco's own restructuring plan and the Rales brothers' higher bid. ${ }^{92}$ At this stage of the takeover battle, retaining the poison pill was a defensive measure disproportionate to whatever remaining threat existed. ${ }^{93}$ Interco could no longer claim that the hostile offer of $\$ 74$ per share was inadequate because, in fact, its bankers had valued its own financial restructuring at $\$ 76$ per share. Moreover, the value to shareholders of the company's reorganization depended on the market's view of the value of the stub. Essentially, shareholders were faced with two competing financial offers: one that was all cash and the other mostly cash (the dividend) plus the stub. ${ }^{94}$ In either case, the pre-offer Interco had disappeared as a company.

In this context, Chancellor Allen gave shareholders the opportunity to choose which of the two offers they preferred and this could only be accomplished by forcing the company to redeem its poison pill. $^{95}$ At least in this type of case, inadequate value as a threat to the shareholders was a temporary problem that could be resolved by allowing a relatively brief period for the financial markets to learn the contested facts from the bidder and the target.

The corporate policy model set forth above is entirely consistent with the Interco opinion. The facts here and in most other cases that applied the Interco's reasoning were quite different from the facts posed in Time-Wamer. ${ }^{96}$ Here, the board had abandoned any existing corporate policy by selling core assets to pay the dividend. The remaining stub of a company was very different from the original corporation. Consequently, the choice confronting shareholders in Interco consisted of two comparable financial deals: (1) the cash deal offered by the raider, or (2) the reorganization with a huge dividend payment and the remaining, highly leveraged stub of a company proposed by Interco. Since the shareholders were faced with alternatives that turned on how the financial market valued the stub in the Interco

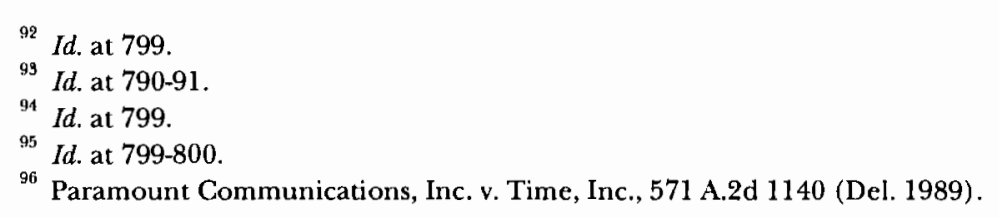


restructuring, Chancellor Allen reasoned that shareholders should be allowed to decide which of the two deals they preferred. ${ }^{97}$

From the perspective of our model, Interco's critical decision was to abandon the original strategic vision of the company held by the managers. Having abandoned its corporate policy, the Interco board gave up its claim of using its private information to pursue a valueenhancing corporate policy. Instead, its new strategy was rooted in an asset sale-financial restructuring with the sole aim of maximizing the stock price. The company could hardly claim that its valuation of the securities that resulted from the restructuring should be favored over the market's valuation.

In our model, Interco stands for the proposition that shareholders should get to choose in those cases where the threat from an unsolicited takeover offer relates directly to shareholders' interests-for example, inadequate value-and where shareholders can evaluate the alternative financial deals being offered to them. ${ }^{98}$

While our model sees the Interco line of cases as correctly decided, we believe that Interco is restricted to those cases in which the target firms abandon a corporate policy in favor of a financial market restructuring. The Delaware Supreme Court reaches a similar conclusion. Although the court did not hear Interco on appeal, we can infer from its later ruling in Time-Wamer that it would have agreed that the Interco board had to redeem its poison pill and allow the shareholders to choose.

As our model would predict, Interco can properly be seen as an element of Revlon. Cases that trigger the enhanced Revlon duties are the cases under Delaware takeover law where shareholder choice rules. If Revlon duties attach, the directors "must focus on one primary objective"-to secure the transaction offering the best value reasonably for the stockholders. ${ }^{99}$ Under the supreme court's analysis in

97 Interco, 551 A.2d at 799-800.

98 See Wachter, supra note 10, at 790-91, 791 nn.20-22 (discussing Interco and other Delaware cases in the context of the debate between management discretion and shareholder choice).

${ }^{99}$ Paramount Communications, Inc. v, QVC Network, Inc., 637 A.2d 34, 44 (Del. 1994). "In the sale of control context, the directors must focus on one primary objective-to secure the transaction offering the best value reasonably available for the stockholders-and they must exercise their fiduciary duties to further that end. The decisions of this Court have consistently emphasized this goal." Id.; see, e.g., Barkan v. Amsted Indus., 567 A.2d 1279, 1286 (Del. 1989) ("[T]he board must act in a neutral manner to encourage the highest possible price for shareholders."); Mills Acquisition Co. v. MacMillan, Inc., 559 A.2d 1261, 1288 (Del. 1989) ("[I]n a sale of corporate 
Revlon, Interco had effectively put itself up for sale when it abandoned its existing corporate policy. ${ }^{100}$ Where companies have either abandoned their existing corporate policy in order to pursue an alternative policy more favored by the financial markets or initiated an active bidding process, there is no need for the courts to favor management discretion because there is no threat to an existing corporate policy.

\section{B. Time-Warner: Management Discretion and Market Mispricing}

Time's pending mega-merger with Warner, coupled with Paramount's hostile bid for Time, presented the Delaware courts with a fact pattern distinct from Interco. When the Rales brothers made their bid, Interco was not involved in a major strategic investment. In response to the bid, Interco abandoned any semblance of a corporate policy. Time, on the other hand, was in the midst of one of the most significant mergers of the period. It was driven by its strategic vision that the future media market required integrated firms with international scope. ${ }^{101}$ Moreover, Time was on the verge of completing the merger before Paramount entered the fray. Given its late arrival, Paramount was asking for an injunction to prevent the merger rather than an injunction forcing a redemption of a poison pill. ${ }^{102}$ This posed an ideal fact pattern for the courts to come to terms with the limitations of the Interco line of cases.

The financial market initially greeted the merger between Time and Warner warmly, with the stock of both companies increasing in price. The post-announcement (anticipated merger) value of Time

control the responsibility of the directors is to get the highest value reasonably attainable for the shareholders.").

${ }^{100}$ Under Delaware law, Revlon duties may be triggered in two circumstances (without excluding other possibilities):

The first, and clearer one, is when a corporation initiates an active bidding process seeking to sell itself or to effect a business reorganization involving a clear breakup of the company.... [The second is] triggered where, in response to a bidder's offer, a target abandons its long-term strategy and seeks an alternative transaction involving the breakup of the company. $637 \mathrm{~A} .2 \mathrm{~d}$ at 43.

${ }^{101} 571 \mathrm{~A} .2 \mathrm{~d}$ at $1143-44$. Time, prior to the case, was primarily a publishing company with some recently developed cable assets such as HBO. By merging with Warner it hoped to vertically integrate so that it could produce the video products that it would distribute through its cable assets, and it wanted Warner's international distribution assets so that it could begin to sell all of its products internationally. Id. at 1143-44. Time's board believed that this plan would maximize the value of the corporation over time. $I d$.

$$
{ }^{102} \text { Id. at } 114142 \text {. }
$$


was approximately $\$ 126$ per share, ${ }^{103}$ which was above the preannouncement price of approximately $\$ 108$ per share. ${ }^{104}$ At this point, Paramount made a cash offer for Time of $\$ 175$ per share, ${ }^{105}$ and subsequently raised its bid to $\$ 200$ per share. ${ }^{106}$ This was a huge premium for Time, whose stock had already appreciated following its announced merger with Warner. When the chancery court forced Interco to redeem its poison pill, the price difference separating the board's proposal and the hostile tender offer was a mere $4 \%,{ }^{107}$ compared to roughly $60 \%$ here. To block Paramount from interfering, Time had to restructure its deal. The original Warner deal was structured as a merger, and after the Paramount bid, it was unlikely that Time's shareholders would vote in favor of it. Consequently, the deal was restructured in a manner that circumvented the need for Time's shareholders to vote. ${ }^{108}$ At this point, Paramount asked the court to block the merger between Time and Warner.

The Delaware Supreme Court's decision in Time-Warner was viewed as a watershed case. ${ }^{109}$ While an application of Unocal's balancing test allowed Interco's shareholders to choose between Interco's restructuring plan and the Rales brothers' bid, the same test precluded Time's shareholders from choosing between Time's bid for Warner and Paramount's bid for Time. Why the difference?

The traditional answer is that Time-Wamer raised a different issue: blocking a merger rather than redeeming a poison pill. The implication is that the chancery court decision in Time-Warmer should be read narrowly as applying to the distinctive features of that case. Chancellor Allen implies this result in his holding. While describing the powers used by the Time board to effectuate the merger as "conventional," he states that a poison pill is very different: "[A] decision not to redeem a poison pill, which by definition is a control mechanism and not a device with independent business purposes, may present

103 Id. at 1147.

${ }^{104}$ Time's closing stock price on March 2, 1989, the day before the board approved the Warner transaction, was $\$ 108.125$. NEW YORK STOCK EXCH., DAILY STOCK PriCE ReCord, Jan., Feb., Mar. 1989, at 414.

${ }^{105} 571 \mathrm{~A} .2 \mathrm{~d}$ at 1147 .

106 Id. at 1149.

${ }^{107}$ See text accompanying notes 88-90.

108 Id. at $1148-49$

109 James A. Fanto, Breaking the Merger Momentum: Reforming Corporate Law Governing Mega-Mergers, 49 BUFF, L. REV. 249, 311 (2001). 
distinctive considerations than those presented in this case." Gilson goes further, arguing that "the Chancery Court opinion in Time-Warner, at least with respect to the proportionality leg of Unocal, simply parallels Interco."111 In brief, Gilson believes that the Delaware Chancery Court was correct in Time-Warmer and that the Delaware Supreme Court got it wrong. ${ }^{112}$

We disagree. We view Time-Warner as presenting a fact pattern to which Interco-type reasoning does not easily apply. Although the shareholder choice approach of Interco was unproblematic when applied to the particular financial restructuring of the mid-1980s, it becomes highly problematic when applied to the corporate policy fact pattern that is raised by Paramount's attempt to defeat the combination of Time and Warner. ${ }^{113}$ Interco involves a matter of alternative financial deals, whereas Time-Warmer deals with alternative strategic corporate plans. The former can be decided by shareholders based on the way the financial markets appraise the alternative deals, whereas the latter requires information that is available to the managers and involves potential market mispricing.

Moreover, contrary to the Gilson position, we view the logic of Chancellor Allen's decision as implicitly recognizing that the shareholder choice approach of Interco does not apply to this type of case. Chancellor Allen states that in the Interco line of cases, "management was presenting and seeking to 'cram down' a transaction that was the functional equivalent of the very leveraged 'bust up' transaction that management was claiming presented a threat to the corporation." On the other hand, in Time-Warner, "the revised transaction, even though 'reactive' in important respects, has its origin and central purposes in bona fide strategic business planning, and not in questions of

${ }^{110}$ Paramount Communications, Inc. v. Time, Inc., Nos. 10866, 10670, 10935 1989 Del. Ch. LEXIS 77, at *88 n.22 (Del. Ch. July 17, 1989).

"II Gilson, supra note 2, at 499.

112 "In particular, the Delaware Supreme Court opinion in Time-Wamer seems simply to have misunderstood the body of law the Chancery Court had created." Id. at 499.

${ }^{113}$ The shareholder choice community correctly viewed the ruling as a major defeat for its cause. The Delaware Supreme Court is portrayed as the villain in the shareholder choice community, not only because it favored the defendant Time, but also because it stated that the Interco doctrine was never Delaware law. The villainy awards need to be shared, however, since many of the critical elements of the supreme court opinion that make the case important were already present in Chancellor Allen's decision. Supra note 12.

${ }^{114}$ Paramount Communications, 1989 Del. Ch. LEXIS 77, at *83. 
corporate control."115 Consequently, Chancellor Allen concludes that the revised merger agreement and the tender offer are reasonable in relation to the specific threat posed by Paramount's bid. ${ }^{116}$ More generally, Chancellor Allen states: "[W]here the board ... continues to manage a corporation for long-term profit pursuant to a preexisting business plan that itself is not primarily a control device or scheme, the corporation has a legally cognizable interest in achieving its strategic plan."

The chancery court argument has most of the building blocks of our corporate policy model. First, it recognizes the central importance of corporate policy in determining the ultimate value of the corporation to its shareholders and that corporate policy is best set by the managers. Specifically, the value of the shareholders' interest in the company "rises or falls chiefly because of the skill, judgment and perhaps luck... of the management and directors of the enterprise." 118 In setting corporate policy the managers are "exercising perfectly conventional powers to cause the corporation to buy assets for use in its business" wishes of a majority of shares." ${ }^{120}$ Second, the chancery court's reasoning recognizes that informational asymmetries may exist so that managers have access to information that the market does not. ${ }^{121}$ It is not, however, that managers are long-term oriented while the market is short-term oriented. "[T]he nature of [an active, informed market for

${ }^{115} I d$. at $* 83-84$

${ }^{116} I d$. at $* 87-88$.

117 Id. at $* 86$.

118 Id. at $* 88-89$.

When [managers] exercise sound or brilliant judgment, shareholders are likely to profit; when they fail to do so, share values likely will fail to appreciate. In either event, the financial vitality of the corporation and the value of the company's shares is in the hands of the directors and managers of the firm.

Id. at $* 89$

${ }^{119}$ Id. at $* 88$

${ }^{120} I$ Id. at *89. Chancellor Allen also comments that, "[i]n fact, directors, not shareholders, are charged with the duty to manage the firm." Id.

${ }^{121}$ According to Chancellor Allen:

Directors may operate on the theory that the stock market valuation is "wrong" in some sense, without breaching faith with shareholders. No one, after all, has access to more information concerning the corporation's present and future condition. It is far from irrational and certainly not suspect for directors to believe that a likely immediate market valuation of the TimeWarner merger will undervalue the stock.

Id. at *56-57. 
shares] is precisely to discount to a current value the future financial prospects of the firm; and . . markets with their numberless participants seeking information and making judgments do this correctly. ..."

Before turning to the heart of the Delaware Supreme Court's decision, it is worth returning to a question raised by Black and Kraakman: Does the Delaware takeover defense theory rest on a flawed belief that the financial markets are myopic? ${ }^{129}$ We believe that the Delaware theory, correctly interpreted, does not rest on such confusion. The controversy arises because the supreme court failed to grasp the chancery court's basis for the long- and short-term distinction. In his decision, Chancellor Allen dealt with the distinction between "managing for current value maximization and managing for longer-term value creation." ${ }^{124}$ His discussion of the financial market was correct and does not imply that financial markets are concerned simply with the short-term whereas corporations are managing for the long-term. ${ }^{125}$

The misinterpretation that markets are short-term oriented arises because investors can sell their stock immediately at whatever the market price is for the shares. The act of selling is a short-run or immediate decision. But the stock price itself is always discounting future profits and thus reflecting long-term strategies. The key distinction is that the financial market is working with limited information regarding long-term prospects in order to place a current value on the stock.

The Delaware Supreme Court is certainly correct when it states that "the question of 'long-term' versus 'short-term' values is largely irrelevant because directors, generally, are obliged to chart a course

${ }^{122}$ Id. at *55. Chancellor Allen goes on to say that even though financial markets are not short-sighted, they still do not, by law, carry the day: "[J]ust as the Constitution does not enshrine Mr. Herbert Spencer's social statics, neither does the common law of directors' duties elevate the theory of a single, efficient capital market to the dignity of a sacred text." Id. at *56.

${ }_{123}$ See supra text accompanying notes $37-39$ (discussing Black and Kraakman's analysis of long- and short-term shareholders).

${ }_{124}^{12}$ Paramount Communications, 1989 Del. Ch. LEXIS 77, at *54.

${ }^{25}$ As Chancellor Allen explains, the "longer-term value creation" is the value creation that occurs when a corporation is able to use what it reasonably believes to be the correct parameters for valuing its investments. The "current value maximization" also has long-term relevance since it is the market presently placing a price on a company, while taking into account what it believes are "the future financial prospects of the firm." Id. at *55. Chancellor Allen realized that financial markets and the shareholders who invest in them are as long-term focused as managers. 
for a corporation which is in its best interests without regard to a fixed investment horizon." ${ }^{266}$ The confusion lies in the fact that they are actually agreeing with the chancery court, while their words suggest disagreement. The bottom line, however, is the same: the supreme court's argument in Time-Warner does not rest on any erroneous belief that financial markets are short-sighted.

Justice Horsey's supreme court opinion adopted Chancellor Allen's corporate policy based decision, but took its implications further; the supreme court agreed that when there is a threat to corporate policy, the board is permitted to take proportionate defensive measures. ${ }^{127}$ However, whereas Chancellor Allen ruled for Time only after satisfying himself that the threat to corporate policy was very real, the supreme court took only a cursory look at the substantiality of Time's claim. Thus, when the defensive strategy is to maintain a threatened corporate policy, the scrutiny that the courts are willing to apply is more limited. The Delaware courts have never been comfortable with "business purpose"-type tests, which require judicial scrutiny of corporate strategies. The supreme court noted in several places that Delaware courts should not be in the business of second-guessing management decisions, as the courts are not the best judges of whether a given corporate policy deserves the protection of particular takeover defenses. ${ }^{128}$

The Delaware Supreme Court also repudiated the Interco line of cases in Time-Warner, while implicitly accepting Chancellor Allen's decision in Interco. The supreme court required Interco to pull its poison pill and allow the shareholders to decide because, by abandoning its long-term strategy in favor of a defensive recapitalization, it had put

\footnotetext{
1989).

${ }^{126}$ Paramount Communications, Inc. v. Time, Inc., 571 A.2d 1140, 1150 (Del.

${ }^{127}$ The Delaware Supreme Court succinctly rejected a narrow reading of Unocal that would exclude threats to corporate policy:

Implicit in the plaintiffs' argument is the view that a hostile tender offer can pose only two types of threats: the threat of coercion that results from a two-tier offer promising unequal treatment for nontendering shareholders; and the threat of inadequate value from an all-shares, all-cash offer at a price below what a target board in good faith deems to be the present value of its shares.... We disapprove of such a narrow and rigid construction of Unocal....

${ }^{128}$ See, e.g., id. at 1153 (rejecting a standard of review that would involve the court "substituting its judgment as to what is a 'better' deal for that of a corporation's board of directors").
} 
itself up for sale. ${ }^{129}$ Interco and its companion cases, in which financial market recapitalizations were adopted as defensive measures, were correctly decided. Still, the broader implications of Interco have been rejected. The supreme court swept the Interco line of cases into one of the situations that triggers Revlon duties.

Although the Delaware Supreme Court has been criticized for repudiating Interco, ${ }^{130}$ the business strategy that gave rise to it became a historical footnote after the court recognized the implications of corporate policy as a cognizable threat under the Unocal test. Prior to Time-Warner, managers believed that their best hope for defending their positions was to offer a competing financial restructuring that the shareholders would find attractive. This was central to the defensive strategies adopted by firms, beginning with Unocal and running through Interco. After Time-Warner, the core defensive strategy became to maintain the existing corporate policy and argue that any hostile tender offer was a threat to the fulfillment of that strategy and, therefore, was not in the shareholders' interest.

The appeal of allowing shareholder choice in fact patterns like Interco lies in the fact that there is no threat to corporate policy because any previously existing policy has been abandoned. Absent a continuing corporate policy, there can be no claim that the financial market is mispricing the future free cash flows that the policy will generate. When there is no threat to the corporate policy, there is no conflict in allowing shareholders to exercise rights of ownership in a contested control setting. When there is such a threat, however, the appeal of shareholder choice is diminished. In this context, it is increasingly up to management, rather than shareholders, to decide the scope of a threat and determine what constitutes an appropriate and proportional response to that threat. Consequently, the threat to the enterprise in terms of a threat to corporate policy overrides the normal rights of ownership.

\footnotetext{
129 "However, Revlon duties may also be triggered where, in response to a bidder's offer, a target abandons its long-term strategy and seeks an alternative transaction involving the breakup of the company." Id. at 1150.

${ }^{190}$ See Gilson, supra note 2, at 501 ("My purpose here is not to criticize the court's doctrinal analysis, although that task commends itself.").
} 


\section{QVC as an Added Trigger of Revlon Duties}

Given our discussion of Time-Warner, how can we reconcile our model with $Q V C ?^{191}$ In the second of the Paramount cases, Paramount was the target rather than the hostile bidder and QVC was the deal jumper as it sought to break up the pending merger of Paramount and Viacom. As was true for Time in Time-Warner, Paramount had a well-informed corporate policy and was attempting to create an integrated media giant. Yet, the court distinguished QVC from TimeWamer based on the fact that Viacom had a controlling shareholder who would remain in control of the combined company. ${ }^{132}$ In its decision, the court made short shrift of Paramount's informed corporate policy argument, and instead held that the proposed merger triggered Revlon duties.

As noted above, our analysis is consistent with Revlon duties in the two types of cases settled before $Q V C$; that is, where the board of directors either "initiates an active bidding process seeking to sell itself" or "where, in response to a bidder's offer, a target abandons its longterm strategy and seeks an alternative transaction involving the breakup of the company." ${ }^{193}$ In both of these types of cases, the directors have voluntarily scrapped an existing corporate policy to fashion a new one more appealing to the financial markets. In so doing, the directors can no longer claim that they are using their superior information to develop a value-enhancing corporate policy.

The remaining question is whether $Q V C$ undercuts our claim that our model provides a theory of Delaware takeover defense law. It does not; and the reason highlights an important feature of the model. The effect of Time-Wamer is to provide some protection to managers who pursue corporate policies that they believe in good faith to be value-enhancing, but may prove to be occasionally unpopular with the financial markets. Consequently, they can maintain takeover defenses should a hostile bidder offer an alternative policy that

\footnotetext{
${ }^{131}$ Paramount Communications, Inc. v. QVC Network, Inc., 637 A.2d 34 (Del. 1994).

${ }^{132}$ Id. at 46-47. Both Time and Paramount were owned by a fluid aggregation of unaffiliated shareholders. This would remain the case in the Time-Warner merger, but would not be the case in the Paramount-Viacom merger, where Paramount's shareholders would have an equity interest in a company with a controlling shareholder. See id. at 43 ("In the event the Paramount-Viacom transaction is consummated, the public stockholders will receive cash and a minority equity voting position in the surviving company. Following such consummation, there will be a controlling stockholder ....")

${ }^{133}$ Paramount, 571 A.2d at 1150.
} 
would become effective if the shareholders tender their shares. In this sense, only managers and not shareholders can choose the firm's corporate policy.

The effect of Revlon has always been to identify and fence off types of corporate policies that trigger enhanced judicial scrutiny. $Q V C$, by adding a third type of transaction that triggers Revlon, merely increased the number of policies fenced off from the managers. In $Q V C$, the supreme court concluded that an important shareholder ownership issue was at stake. Specifically, the court argued that voting rights are a valuable property right of ownership and that such voting rights become "mere formalities where there is a majority shareholder." ${ }^{134}$ The court reasoned that since public shareholders can sell control only once, that sale ought to be made to the highest bidder.

We interpret the Delaware Supreme Court's enterprise-ownership dichotomy as saying that shareholders get to decide ownership issues-such as the right to sell their shares to a hostile bidder-unless it materially affects the ability of the managers to use their superior information to develop value enhancing corporate policies. The $Q V C$ decision does not have this adverse effect on management discretion to manage and thus the decision does not conflict with our model.

We do not undertake here an examination of whether QVC-type change of control cases represent a warranted expansion of Revlon's borders. ${ }^{135}$ The supreme court's theory in $Q V C$ raises a number of questions, including its apparent assumption that the "minority" shares that trade on financial markets "under-value" the corporation. These questions, however, fall outside the focus of this Article.

${ }^{134}$ QVC, 637 A.2d at 42.

135 The supreme court offered two related explanations for extending Revlon to change of control transactions where a corporation owned by a "fluid aggregation of unaffiliated stockholders" is being merged into a corporation that will have a majority shareholder. Id, at 43. The first explanation is that the shareholder vote is one of the valuable rights owned by shareholders and such rights become "mere formalities where there is a majority shareholder." Id. at 42 . The second and related explanation is that transactions involving minority shares-such as those traded on stock exchanges-trade at a discount to transactions involving changes of control. See id. at 43 ("The acquisition of majority status and the consequent privilege of exerting the powers of majority ownership come at a price. That price is usually a control premium which recognizes not only the value of a control block of shares, but also compensates the minority stockholders for their resulting loss of voting power."). The court derives from these assumptions that the sale of control is a one-time right of shareholders and thus when the directors sell control they should be required to sell to the highest bidder as required by Revlon. 
Assuming that $Q V C$ continues to be read narrowly to apply to transactions involving the sale of control to a controlling shareholder, then its restriction on the exercise of informed corporate policy is small. $^{136}$ As long as the legal rules are known, the directors can pursue whatever corporate policy they prefer with the exception of the small subset of policies that trigger Revlon duties. Consequently, the existence of Revlon land (the collection of corporate policies that trigger the duty) does not provide incentives for managers to manage to the market because managers can avoid finding themselves in an exposed position, vulnerable to a hostile tender offer by avoiding Revlontriggering policies. The agency cost problem emerges in our (second) model when managers cannot avoid the exposed position and hence choose to manage to the market to maximize the share price and minimize the likelihood of a hostile tender offer.

A related question to the scope of Revlon duties is the permissible degree of management discretion that is permitted when those duties attach to a transaction. While the $Q V C$ court clearly extended the scope of Revlon, it also may have increased the permissible degree of management discretion in stock mergers, such as $Q V C$. It did so by inserting the critical language from Time-Warmer with respect to management discretion; namely that Delaware courts would not secondguess corporate policy because it would "involve the court in substituting its judgment as to what is a 'better' deal for that of a corporation's board of directors." "37 Specifically, in addressing Revlon's enhanced

${ }^{196}$ On the other hand, if the QVC change of control doctrine were applied expansively, it would more broadly restrict the ability of managers to adopt value-enhancing corporate policies by fencing off a broad array of corporate policies. This does not appear to be an issue, although the claim that Revlon duties attach whenever shareholders lose their opportunity to receive a control premium is troublesome given the uncertain grounds on which the control premium theory is based. See In re NCS Healthcare, Inc., S'holders Litig., 825 A.2d 240, 254-55 (Del. Ch. 2002), rev'd on other grounds sub nom Omnicare, Inc. v. NCS Healthcare, Inc., 818 A.2d 914 (Del. 2003) (refusing to apply Revlon duties in connection with a stock-for-stock merger in which the stockholders would receive shares of an issuer without a controlling person or group); Arnold v. Soc'y for Sav. Bancorp, Inc, 650 A.2d 1170, 1289-90 (Del. 1994) (failing to apply Revlon duties in part because the plaintiff still had the opportunity to receive a control premium in the future). But see John C. Coffee, Jr., Under the "Merger of Equals" Doctrine, Can a Target Board Always Favor a Friendly Suitor When a Second Bidder Makes a Higher, Unsolicited Offer?, NAT'L L.J., Mar. 30, 1998, at B5 (noting that a target board can avoid Revlon duties by manipulating the transaction so that it resembles a "merger of equals" (e.g., by using stock rather than cash, dividing the board of the surviving entity equally between the two sides, and failing to create a control block so that a control premium can still theoretically be obtained at some later point)).

${ }^{197}$ Paramount, 571 A.2d at 1153 . 
judicial scrutiny, the court acknowledged "the complexity of the directors' task in a sale of control ... in investigating and selecting the best value" and then reasserted that the court "will not substitute [its] business judgment for that of the directors." ${ }^{138}$

In summary, our corporate policy model explains the rationale for allowing shareholders to decide the outcome in the Revlon cases when the directors abandon an existing corporate policy, either by initiating a bidding process or abandoning its policy in response to a hostile tender offer. The Interco line of cases fit into these two categories. The model also explains the necessity of protecting management discretion in Time-Warner. Even QVC can be fit into our model, and in doing so, it highlights an important feature of the policy. That is, our model is consistent with a demarcation line that only allows management, but not shareholder/hostile bidders to initiate changes in corporate policy. In effect, management can choose whatever informed corporate policy it believes in good faith to be in the interests of the corporation and its shareholders. The one restriction is that it would not choose the policies that trigger Revlon duties when it does not wish to be guided by those duties. As long as the scope of Revlon is narrowly drawn, the reduction in management discretion is correspondingly small.

\section{CONCLUSION}

Delaware corporation law has long been criticized for lacking a coherent theory to justify its apparent reliance on management discretion as a rule to govern takeover defenses. Certainly there are many unresolved questions. We maintain, however, that there is a coherent theory to validate the critical elements that make up the core of what we take to be the Delaware rule. Our presentation of the animating principles is based on a model of corporate policy operating in the context of financial markets where strong form efficiency is absent.

\footnotetext{
${ }^{198}$ QVC, 637 A.2d at 45 . "The board of directors is the corporate decisionmaking body best equipped to make these judgments. Accordingly, a court applying enhanced judicial scrutiny should be deciding whether the directors made a reasonable decision, not a perfect decision. If a board selected one of several reasonable alternatives, a court should not second-guess that choice even though it might have decided otherwise or subsequent events may have cast doubt on the board's determination. Thus, courts will not substitute their business judgment for that of the directors, but will determine if the directors' decision was, on balance, within a range of reasonableness." Id.
} 
Our model generates two broad conclusions or themes that are central to a positive theory of Delaware takeover law and related doctrine. The first is that, as long as the directors and their appointed managers have the best information about the array of investment opportunities available to the corporation, granting informed directors and managers the right to manage the business and affairs of the corporation will maximize the value of the corporation and the shareholders' interest. To accomplish this, however, the directors and managers need to be able to conduct corporate policy without secondguessing by the courts and interference from shareholders. This provides the basis for a management discretion rule.

As long as managers are better informed than shareholders as to the value of alternative corporate policies, giving shareholders the choice to decide is not in the shareholders' interests. The issue here is not one of the so-called short-term focus of shareholders and financial markets versus the so-called long-term focus of managers. Financial markets and the shareholders who invest in them are as long-term focused as are managers. The difference is the information set upon which they act.

The second theme encompasses both the need to control agency costs and the sometimes unappreciated complexity of doing so. Providing for management discretion creates the potential that directors and managers will not maximize the value of the shareholders' interest in the corporation. Instead, they will act in their own interests to secure private benefits. When confronted by a hostile tender offer that is in the best interests of shareholders, they may reject the offer so as to entrench themselves and protect the private benefits of control.

If financial markets efficiently and continuously set stock prices at their fundamental value, then investors would be as informed as managers as to the value of the corporation and could best decide the outcome of contested control transactions. A shareholder choice rule would then provide incentives for managers not to seek private benefits because the higher the private benefits, the lower the price of the stock and the more vulnerable to hostile tender offers. Consequently, a shareholder choice regime would minimize agency costs.

In a world where financial market mispricing occurs because of failures of strong form efficiency, shareholder choice can generate perverse results. The managers who are vulnerable to hostile tender offers are those whose stock is most underpriced, and there is no particular reason that this is correlated with the amount of private benefits secured by the managers. In this context, managers best protect 
their positions by minimizing the chances of having their stock underpriced. In our model, this is accomplished by managing to the market, which occurs when well-informed managers cater to the market by making suboptimal investment choices. Managing to the market enables the managers to avoid underpricing by the less well informed investors in the market. Moreover, the rational managers would not wait until the tender offer is made to manage to the market. If the legal rule creates an incentive for managers to manage to the market in the last period, it is rational to adopt this strategy when mispricing first occurs and to continue to do so in subsequent mispricing periods.

Managing to the market is an agency cost, but a type that has not been considered in the corporate law literature. The reason is that corporate law scholarship has yet to integrate the evidence found in the empirical corporate finance literature concerning financial market mispricing. Managing to the market leads to over- or underinvestment, depending on whether the financial market overestimates or underestimates the company's true discount factor.

Which of the two types of agency costs is larger, managers rejecting hostile tender offers in order to secure their private benefits of control or managers entrenching themselves by managing to the market, is ultimately an empirical question. It is, however, certainly reasonable for the Delaware courts to believe that the agency costs associated with a shareholder choice regime are larger than those associated with a management discretion regime.

We conclude that the Delaware takeover law does have animating principles and that these are the same principles that infuse other aspects of Delaware law. Here we return to the essential tension noted by Chief Justice Veasey in his discussion of Delaware law: the tension between enterprise issues and ownership issues. ${ }^{139}$ The ownership issue at stake here is the right of investors to sell their stock to whomever they choose. The conflict is the ability of managers to defend what they perceive to be the best interests of the corporation. In the corporate law scholarship, the unstated assumption is that this conflict can effectively be cornered in to the last period. In other words, the battle is fought and the incentive effects are felt in the period after the tender offer is made.

\footnotetext{
139 See Veasey, supra note 50, at 394 ("Corporate governance issues often divide among 'enterprise' and 'ownership' issues in corporate decision-making ....").
} 
Our model of corporate policy challenges that assumption. As stated above, a shareholder choice rule that exerts pressure on directors to manage to the market in the last period will lead them to do so in earlier periods of mispricing as well. Although shareholder choice protects ownership rights, it badly strains the fundamental enterprise goal of achieving an informed corporate policy. Our model shows that when faced with the risk of fracturing corporate policy goals, the Delaware courts' solution, which protects the ability of directors to manage to their best information, is, at least arguably, the best rule. 